Debreceni Jogi Múhely 2020. (XVII.) 3-4.

Debreceni Egyetem, Állam- és Jogtudományi Kar, Debrecen

(University of Debrecen, Faculty of Law, Debrecen)

DOI 10.24169/DJM/2020/3-4/11

Zsurzsa Zsolt

hallgató

Szegedi Tudományegyetem Állam-és Jogtudományi Kar, Civilištikai Tudományok Intézete

\title{
A BÍRÓSÁGI JOGKÖRBEN OKOZOTT KÁRÉRT VALÓ FELELŐSSÉG ÉS AZ ÜGYVÉDI FELELŐSSÉG ÖSSZEHASONLÍTÁSA A FELELŐSSÉGI MÉRCE SZEMPONTJÁBÓL
}

Debreceni Jogi Műhely, 2020. évi (XVII. évfolyam) 3-4. szám (2020. december 30.)

DOI 10.24169/DJM/2020/3-4/11

Abstract: It is a basic requirement of society that those who are infringed upon in exercising their rights, may enforce the sanctions of the infringement in a judicial process. This process is mainly executed by state courts in most legal systems, which are supposed to settle legal disputes by interpreting the relevant laws, and by taking the relevant case law into consideration. However, this is a complex process that requires professional legal knowledge from the parties. Attorneys are meant to be those professionals, who help people seeking justice to obtain their respective compensation, and also with other problems requiring legal expertise. The attorneys shall also execute this ask to the best of their knowledge. In some cases, however, this legal enforcement process may fail, which may result in the person seeking legal advice or compensation to lose its opportunity to pursue its claim permanently.

This case might happen as a result of the actions or omissions of courts, or that of attorneys. In these cases, it is logical that the liability of these two actors of justice for the parties' damages may be decided upon by assessing the quality of work that has led to a person suffering material damages. It would be easy to assume that the standard for the reasonable conduct for both actors is very high. However, apparently the standard for the reasonable conduct of courts seems to be a lot lower than that of attorneys in the judicial practice. In practice, only in case of the most severe infringements of courts may the injured parties receive compensation for damages, while a lot less severe infringement - or even quite the same infringements - may result in the attribution of the attorney's liability.

I intend to analyze this difference in the civil liability of the two actors in the light of the legal background, legal practice and the different tasks of courts and attorneys as well as the reasons of this phenomenon, and form an opinion on whether it can be justified or this practice should be discouraged. To do so, I analyze the relevant Hungarian judicial practice and legal science, and cite some foreign examples as well.

Keywords: civil law liability for the actions of courts, civil law liability for attorneys, standard of reasonable conduct, civil law liability of the state, civil law liability of public authorities

Absztrakt: A tanulmány elsősorban a szerződésen kívüli károkozásért való felelősség egyik speciális alakzatára, a bírósági jogkörben okozott kárért való felelősségre koncentrál. Az utóbbi évek gyakorlata azt mutatja, hogy a bíróságokkal szemben indított kártérítési perek elhanyagolható hányadában marasztalják az eljárt bíróságokat a jogértelmezési vagy jogalkalmazási hibáikkal a feleknek okozott károk miatt. Indokolt ezért annak vizsgálata, hogy ennek a jelenségnek milyen okai lehetnek, valamint, hogy ezek az okok indokolják-e ezt a gyakorlatot. A vizsgálat eredményeként több olyan tényező is azonosítható, amelyek külön-külön is rendkívüli módon megnehezíthetnék a bíróságokkal szembeni igényérvényesítést, kombinálva pedig szinte lehetetlenné teszik azt. Ezen tényezők között elsősorban a kirívóan súlyos jogsértés doktrínáját, valamint a keresetet a jogerős bírósági döntések tartalmi immunitására hivatkozással elutasító ítéleteket lehet megjelölni. 
Debreceni Jogi Múhely 2020. (XVII.) 3-4.

Debreceni Egyetem, Állam- és Jogtudományi Kar, Debrecen

(University of Debrecen, Faculty of Law, Debrecen)

DOI 10.24169/DJM/2020/3-4/11

Kutatásmódszertani szempontból célszerú volt a bíróságok kárfelelőssége kapcsán tett megállapításokat szembe állítani az ügyvédség kárfelelősségének bírói gyakorlatával, ahol egyértelmúen megállapítható volt, hogy a bíróságok sokkal szigorúbb elvárhatósági mércét támasztanak, mint a bíróságokkal szemben, holott a két jogászi hivatásrend társadalmi felelőssége és munkaterhe ezt nem indokolná. Összehasonlításra került a két jogászi hivatásrend kárfelelősségének történeti kialakulása, a felelősségük jogszabályi háttere és a kapcsolódó joggyakorlat, rövid kitekintést téve külföldi példákra is. Az átfogó elemzés alapján javaslatok megfogalmazására kerül sor a jogalkalmazás és a jogalkotó számára is.

Kulcsszavak: bírósági jogkörben okozott kár, ügyvédi kárfelelősség, elvárhatósági márce, állami kárfelelősség, közhatalom gyakorlásával okozott kár

Alapvető társadalmi igény, hogy akit jogaiban megsértenek, szükség esetén állami úton kikényszeríthesse a jogsértés következményeit. Erre a célra a legtöbb jogrendszerben az állami bíróságok hivatottak elsődlegesen, amelyek optimális esetben a jogszabályok megfeleló értelmezésével, szem előtt tartva az egységes joggyakorlat követelményét, meghozzák azt a döntést, amely az adott jogvitára irányadó jogszabályoknak megfelel. Ez azonban egy komplex, laikus személyek számára nehezen érthető folyamat - azaz bírósági eljárás - révén érhető el, amelyben fontos, hogy a jogkereső személyek igényüket ténybeli és jogi alapon megfelelően alátámasszák. Ennek a feladatnak - és más, jogi szakértelmet igénylő feladatoknak - az ellátására az emberek megfelelő felkészültségú, a jog múködését ismerő ügyvédeket bízhatnak meg, akik legjobb tudásuk szerint kötelesek ügyfelük képviseletét ellátni a bíróság előtt. Ám előfordulhat, hogy az előbb leírt folyamat valamilyen módon félresiklik, és a jogkereső személy - akár véglegesen - elesik attól a lehetőségtôl, hogy az ốt a jogszabályok alapján megillető követelését érvényesítse, illetve ahhoz hozzájusson.

Ez a nem kívánatos jelenség mind a bíróságok, mind az ügyvédek tevékenységének eredményeként bekövetkezhet. A joggyakorlat mégis abba az irányba mutat, hogy amikor valaki az ilyen jellegủ sérelmét bírói úton kívánja orvosoltatni, a jogalkalmazás rendkívül eltérő hozzáállást mutat a bíróságok, illetve az ügyvédek által a jogalanyoknak kárt okozó hibáival szemben. Ugyanis a gyakorlat szerint a bíróságoknak csupán a rendkívül - kirívóan - súlyos jogsértései, míg az ügyvédeknek sokkal kisebb mérvủ hibái alapozzák meg felelősségüket az ügyfeleknek okozott kárért.

Azt gondolom, hogy rendkívül érdekes kérdés annak a vizsgálata, hogy a jogszabályi háttér, a bíróságok és az ügyvédség eltérő feladatai, valamint a joggyakorlat fényében, ennek a jelenségnek mik az okai, megfelelő gyakorlat-e ez, és van-e szükség változtatásra akár jogalkotói, akár jogalkalmazói szempontból. Mindezen kérdések feltárása érdekében igyekszem bemutatni azt, hogy a joghoz jutás két említett szereplője felelősségének mi az alapja, ebből kiindulva pedig elemzés alá kívánom vonni, hogy a bíróságok, valamint az ügyvédek számára a bíróságok (és a jogirodalom) által felállított felelősségi mérce hogyan viszonyul egymáshoz, és az eltérésekbő́l milyen következtetések vonhatók le. Mindezt a releváns magyar joggyakorlat, valamint a téma dogmatikai hátterének bemutatásával kívánom véghezvinni, összehasonlításképpen értekezve külföldi példákról is.

\section{A bírósági és az ügyvédi kárfelelősség hatályos jogszabályi keretei}

\subsection{A birósági jogkörben okozott kárért való felelösség hatályos jogszabályi körmyezete és gyakorlata}

A 2013-as Ptk. a bírósági jogkörben okozott kárért való felelősség szabályozásában alapvető változást nem hozott az 1959-es Ptk.-nak az új Ptk. hatályba lépését közvetlenül megelőző rendelkezéseihez képest, azonban ebben érdemes részletesen elemezni a bírósági kárfelelősség feltételrendszerét, mivel az új Ptk. elfogadását megelőző évtizedben a bírói gyakorlat számos döntésében formálta az egyes feltételek konkrét határait.

Jelenleg a hatályos Ptk. 6:549. §-a rendelkezik a bírósági jogkörben okozott károkért viselt felelősségről, a „Felelősség bírósági, ügyészségi, közjegyzői és végrehajtói jogkörben okozott kárért” cím alatt. Az előbbi szakasz visszautal a közigazgatási jogkörben okozott kárért való felelősséget rendező 6:548. §-ra, 
Debreceni Jogi Múhely 2020. (XVII.) 3-4.

Debreceni Egyetem, Állam- és Jogtudományi Kar, Debrecen

(University of Debrecen, Faculty of Law, Debrecen)

DOI 10.24169/DJM/2020/3-4/11

amikor kimondja, hogy a bírósági jogkörben okozott kárért való felelősségre a közigazgatási jogkörben okozott kárért való felelősség szabályait kell megfelelően alkalmazni, azzal, hogy a kárigényt bírósági jogkörben okozott kár esetén a bírósággal szemben kell érvényesíteni. A korábbi szabályozáshoz képest a Ptk. pontosítja a perbeli legitimációra vonatkozó szabályokat, amikor kimondja, hogy a jogi személyiséggel nem rendelkező bíróságok elleni kárigényeket az előtt a bíróság előtt lehet érvényesíteni, amelynek elnöke a nem jogi személy bíróság bírái tekintetében az általános munkáltatói jogkört gyakorolja. Ez a gyakorlatban a jelenlegi bírósági szervezetrendszert tekintve azt jelenti, hogy a járásbíróságok, valamint a 2020. március 31-ig múködő közigazgatási- és munkaügyi bíróságok elleni kártérítési pereket az adott bíróság másodfokaként működő törvényszék ellen kell első fokon megindítani.

Mivel a kárfelelősség egy speciális fajtájáról van szó, a felelősség megállapításához a kártérítési felelősség Ptk. 6:519. \ szerinti általános, és 6:549. \ szerinti különös feltételeinek is teljesülnie kell. Így a bírósági jogkörben okozott károk megtérítése érvényesítésének a feltételeit az alábbiak szerint lehet összefoglalni:

1, Jogellenes magatartás (bírósági jogkörben kifejtett)

2, Kár bekövetkezése

3, Okozati összefüggés a kár és a jogellenes magatartás között

4, Felróhatóság (és ebben a körben a kirívóan súlyos jogsértés követelménye) (Vékás - Gárdos, 2018)

5, Rendes jogorvoslati lehetőségek kimerítése

Mivel a kárfelelősség egy igen speciális köréről van szó, mindezen feltételek fennállásának esetköreit a bírósági gyakorlatnak kellett kimunkálnia. A bírósági jogkörben okozott károk megtérítéséért való felelősség egyes feltételeinek vizsgálatát a gyakorlat a különös feltételek, azaz a rendes jogorvoslati lehetőségek kimerítésével, és a bírósági jogkör megállapíthatóságának vizsgálatával kezdi. (Vogyicska, 2015); (Borbás, 2014) Ennek az az egyszerú oka, hogy ezen feltételek fennállásának vizsgálata tulajdonképpen könnyen bizonyítható ténykérdések vizsgálatát jelenti. Azaz, a bírósági jogkörben okozott kár megtérítése iránti igényt elbíráló bíróságoknak megfelelő szûrôt jelent a kereset vizsgálatát a különös feltételek fennállásával kezdeni, mivel, ha ezek a feltételek nem állnak fent, a keresetet anélkül lehet elutasítani, hogy a jóval összetettebb és hosszadalmasabb elemzést kívánó általános feltételek fennállását vizsgálni kellene. Ebből kifolyólag, a tanulmány is ezt a sorrendet követi.

\subsubsection{A rendes jogorvoslat kimerítése és a bírósági jogkör}

A rendes jogorvoslati lehetőségek kimerítésének követelménye azt a későbbiekben részletesebben kifejtett jogpolitikai célt szolgálja, hogy a bírósági jogkörben okozott károk megtérítése iránti perek ne váljanak elsődlegessé a károkozással összefüggésben igénybe vehető rendes jogorvoslatokhoz képest. (Borbás, 2014) A rendes jogorvoslati lehetőség igénybe vételének kötelezettsége egyébként az általános kárenyhítési és kármegelőzési kötelezettségnek a bírósági jogkörben okozott károk területének speciális szabályaként is meghatározható. (Az új Polgári Törvénykönyv koncepciója; Debreceni Ítélőtábla Pf. 20.289/2011)

A hatályos Ptk. nem hagy kétséget afelől, hogy a bírósági jogkörben okozott károk megtérítéséhez a felperesnek a rendes jogorvoslati lehetőségeket kell kimerítenie. Ebből következik, hogy rendkívüli perorvoslattal, azaz felülvizsgálati vagy perújitási kérelemmel igénye érvényesítéséhez a félnek nem kell élnie. Ugyan a törvény szövegéből valóban az következik, hogy a rendkívüli jogorvoslatok kimerítése nem feltétele a kárigények érvényesítésének a bíróságokkal szemben, de ahogy Fuglinszky is mondja, ez nem zárja ki, hogy ezen jogorvoslati lehetőségek elmulasztását felróható károsulti közrehatásként értékeljék az eljáró - mint később részletesebben kifejtésre kerül, rendkívül szigorú szemléletet képviselő - bíróságok, s erre alapozva kármegosztás mellett döntsenek. (Fuglinszky, 2015) A „kimerítés” kifejezés a jogszabály megfogalmazásában a nyelvtani értelmezés alapján áláspontom szerint csak arra az esetre utal, amikor a fél a rendes jogorvoslati lehetőségeket igénybe vette, azonban ez a megfogalmazás - megint csak a nyelvtani értelmezés alapján - nem tartalmazza azt az esetkört, 
Debreceni Jogi Műhely 2020. (XVII.) 3-4.

Debreceni Egyetem, Állam- és Jogtudományi Kar, Debrecen

(University of Debrecen, Faculty of Law, Debrecen)

DOI 10.24169/DJM/2020/3-4/11

amikor az adott bírósági magatartással vagy mulasztással szemben egyáltalán nincs is jogorvoslati lehetőség. Ezért fontos utalni a Ptk. 6:549. \azon rendelkezésére, amely a bírósági jogkörben okozott kárért való felelősségre a közigazgatási jogkörben okozott kárért való felelősség szabályait rendeli megfelelően alkalmazni, eltérést csupán a felelősség alanya tekintetében (amely jelen esetben a bíróság) fogalmaz meg. A közigazgatási jogkörben okozott károkért való felelősségről szóló 6:548. \ pedig akként fogalmaz, hogy az igény érvényesítésének előfeltétele az, hogy a kár ne legyen elhárítható rendes jogorvoslattal. Álláspontom az, hogy a hatályos szabályozásban ezen logika mentén a bírósági jogkörben okozott károkért való felelősségnek továbbra is megfelelő feltétele lehet az is, amikor az adott jogsértéssel szemben nincs helye jogorvoslatnak. Ennek kapcsán a Kúria egy eseti döntésében például megállapította, hogy a felperes jogosult volt bírósági jogkörben megsértett személyiségi joga miatt igényt érvényesíteni, amikor az alperes bíróság a Be. szabályainak megsértésével rendelte elő elővezetését az adott tárgyalásra, mivel a Be. az elôvezetéssel szemben nem biztosított formális jogorvoslati lehetőséget. (Kúria Pfv. 20.185/2016/7)

A joggyakorlatban az elmúlt évtizedekben a rendes jogorvoslat kimerítése kapcsán számos meghatározó jelentőségű döntés látott napvilágot. Egy közzétett eseti döntésben például meghatározásra került a rendes jogorvoslat kimerítése követelményének alapvető tartalma, mely szerint „a kártéritési perben a biróságnak azt kell viqsgálnia, hogy a kár okozójaként megjelölt intézkedés vagy mulasztás tekintetében a károsult a kár elháritásához szülkséges jogorvoslat lehetöségét kimerítette-e." (BH 2008.120) Azaz mindig az adott konkrét károkozó cselekmény kapcsán igénybe vehetó, a kár orvoslására alkalmas jogorvoslatok fél általi igénybe vételét kell vizsgálni. A rendes jogorvoslatok körébe tartozhat a bírósági jogkörben okozott károk megtérítése iránti perek kapcsán is a fizetési és a bírósági meghagyással szemben előterjesztendő ellentmondás, a határozatok elleni fellebbezés, a kijavítási, kiigazítási, kiegészítési kérelem, valamint az igazolási kérelem is. (Pribula, 2014) További feltételként várja el a bírósági gyakorlat - jogosan - hogy a rendes jogorvoslat iránti kérelem érdemben elbírálásra kerüljön. (lásd pl. LB Pf. 25.292/2000) A kárigényüket érvényesíteni kívánó felek érdekeit védő gyakorlatnak tekinthetô az, hogy a bíróságok a rendes jogorvoslat kimerítése feltételének hiánya miatt nem zárják el a jogkeresőket az igényérvényesítéstől olyan esetekben, amikor a jogorvoslati lehetőségről való tájékoztatást az alapügyben eljáró bíróság elmulasztotta. (BH 2003.154) Fontos ugyanakkor leszögezni, hogy az újabb joggyakorlatban már található olyan közzétett eseti döntés, amely kifejezetten kinyilvánította, hogy a rendes jogorvoslat lehetőségének kimerítése objektív körülmény, amelyet nem a felróhatóság körében kell vizsgálnia a bíróságnak, ezért elmulasztása esetén kimentésnek sem lehet helye. (BDT 2017.3720) Mindebből az a következtetés szưrhető le, hogy amennyiben a bíróság a jogszabályoknak megfelelő tájékoztatást nyújt a félnek a rendelkezésére álló jogorvoslati lehetőségrôl, és a fél ennek ellenére nem él jogorvoslattal - függetlenül például attól, hogy volt-e jogi képviselője, vagy sem - nem lesz jogosult a bírósági jogkörben keletkezett kárának a megtérítésére.

A másik fontos különös feltétele a bírósági kárfelelősség megállapításának, hogy a károkozó magatartásnak bírósági jogkörben megvalósított tevékenységnek vagy mulasztásnak kell lennie. A korábbi Ptk. kapcsán irányadó PK 42. számú állásfoglalás fogalom-meghatározása álláspontom szerint jelen téma szempontjából továbbra is elemzendő: „Államigazgatási jogkörben okozott kárnak (ide értve a birósági jogkört is) az államigazgatási jellegü, tebát a közhatalom gyakorlása során kifejtett særervezón-intéžedó tevékenységgel, illetöleg ennek elmulasztásával okozott kárt lehet tekinteni." Azaz azok a műszaki, gazdasági jellegư tevékenységek, amelyek ugyan az államigazgatás múködéséhez közvetve kapcsolódnak, és vagyoni kár vagy személyiségi jogsértés okozására alkalmasak lehetnek (az állásfoglalás példaként lépcsők, világitás nem megfelelő karbantartását hozza példaként), nem tartoznak az államigazgatási (bírósági) jogkörben okozott károk alapjául szolgáló magatartások közé. Ezen mulasztások, tevékenységek következményeként bekövetkezett károkért más felelősségi (pl. általános, deliktuális kárfelelősség) alakzat alapján lehet igényt érvényesíteni. A bírósági gyakorlatból származik a bírósági jogkör következő meghatározása: „Bírósági jogkörben okozott kárról akkor lehet sqó, ha az az igazságszolgáltatás gyakorlásával, tehát a biróság feladatainak teljesitése körében megvalósitott tevékenységgel, vagy mulasżással okozati összefüggésben keletkęzett." BH 2013.45) Azt gondolom, hogy ez a meghatározás elég pontosan leírja, hogy a PK 42. számú állásfoglalásban az államigazgatási jogkörre leírtakat a bírósági jogkörben okozott károk megtérítése iránti perek tekintetében úgy kell értelmezni, hogy a bíróságok által gyakorolt közhatalmi (azaz igazságszolgáltatási) tevékenység keretében kifejtett magatartások 
Debreceni Jogi Műhely 2020. (XVII.) 3-4.

Debreceni Egyetem, Állam- és Jogtudományi Kar, Debrecen

(University of Debrecen, Faculty of Law, Debrecen)

DOI 10.24169/DJM/2020/3-4/11

szolgálhatnak a felelősség alapjául.

\subsubsection{Jogellenesség}

A jogellenesség problematikája kevéssé merülhet fel, mivel a Ptk. 6:520. \-ban felsorolt jogellenességet kizáró okok a bírósági jogkörben okozott károkkal összefüggésben ritkán merülhetnek fel, ráadásul a károsultnak a kárát kell bizonyítania, a jogellenességet külön nem. (Vogyicska, 2015) Ez abból következik, hogy a károkozó magatartás jogellenessége magából a károkozás tényéből következik. (Csécsy - Kiss - Varga, 2019) Egyet lehet érteni Vogyicska Petra azon álláspontjával, hogy ez talán akkor fordulhat mégis elő, ha perbeli egyezséget kötnek a felek, amelyet a bíróságnak jóvá kell hagynia. Mivel ilyenkor a fél tulajdonképpen beleegyezett a vagyonában bekövetkezett értékcsökkenésbe, ezért az egyezség kizárhatja a kár jogellenességét. (Vogyicska, 2015; valamint Legfelsőbb Bíróság Pf. 25.079/2001/4.)

A jogellenesség témaköre kapcsán érdemes megemlíteni azt a bírósági joggyakorlatban a mai napig aktuális kérdést, hogy a bírósági jogkörben okozott kár tárgyában eljáró bíróság döntése mennyiben egyeztethető össze a per tárgyául szolgáló alapeljárásban hozott döntés jogerejével. A bíróságok szervezetéről és igazgatásáról szóló 2011. évi CLXI. törvény (Bszi.) 2. \-a ugyanis elvi éllel mondja ki, hogy „A bíróságok a vitássá tett jogról [...] véglegesen döntenek.” A Bszi. 6. \-a pedig akként rendelkezik, hogy a bíróság határozata mindenkire kötelező. Márpedig a bírósági jogkörben okozott kár kérdésében döntô bíróság adott esetben nem mást tesz, mint egy már jogerős, de jogszabálysértő bírósági döntés meghozatalában, vagy a bíróság mulasztásban megnyilvánuló jogszabálysértését mondja ki, és a félnek ezzel a magatartással okozott károk megtérítésére kötelezi az alapügyben eljárt bíróságot. Számos bírósági döntés értelmezte ezt a jelenséget úgy, hogy a bírósági jogkörben okozott kár megtérítése iránti perben eljáró bíróság tulajdonképpen az alapügyben eljáró bíróság határozatának jogerejét megsértve felülvizsgálná az alapügyben hozott határozatot, amikor annak jogellenességét állapítaná meg. (lásd BH 1993.32., BH 2000.55., BH 2003.65., BH 2009.9., BDT 2006.1496., valamint Győri itélótábla Pf.20.070/2015/6., Fôvárosi Törvényszék P.22.586/2015/12) Ez az álláspont helyesnek is mondható azokban az esetekben, amikor a bírósági jogkörben okozott kár iránti igényét érvényesíteni kívánó fél nem a konkrét jogellenes magatartást, hanem magát a jogerôs döntés teljes tartalmát jelöli meg követelése alapjául. (Tókey, 2017) Ugyanakkor fontos ezt az esetet elhatárolni attól, amikor az előzményügyben eljárt bíróság kárt okozó döntésének/eljárásának jogellenességére történik hivatkozás. Ugyanis amikor a bírósági jogkörben okozott kár ügyében eljáró bíróság megállapítja, hogy az alapügyben eljárt bíróság döntése/eljárása jogellenes volt, és emiatt kártérítés megfizetésére kötelezi, nem a jogerős döntését bírálja felül, nem változtatja meg az alapügyben hozott döntést, hanem pusztán a döntés/eljárás jogellenes voltából fakadóan okozott károk megtérítését rendeli el. Ezt a Bszi.-ben rögzített véglegesség és minősített kötőerő nem zárja ki, hiszen ezen joghatások azt jelentik, hogy a felek ugyanabból a ténybeli alapból, azonos jog érvényesítése iránt egymás ellen pert nem indíthatnak, valamint, hogy a bíróság döntése mindenkire kötelező. Az utóbbi joghatásokon a bírósági jogkörben okozott kár megtérítésére kötelezés nem változtat, csupán a félnek a jogellenes döntésből/eljárásból származó vagyoni hátrányát kompenzálja. Az alapügyben eljárt bíróság esetleges károkozó magatartása vagy mulasztása, illetőleg az ebből származó esetleges kártérítési felelősség fennállása ugyanis az alapperben nyilvánvalóan nem képezték vizsgálat tárgyát és ezért annak eredménye sem jelenhetett meg a jogerős ítéletben, tehát a jogazonosság a két ügy között nem állapítható meg. A jogellenesség megállapításának tilalma a bírósági jogkörben okozott károk megtérítéséért való felelősség alakzatát kiüresítené, hiszen annak éppen az a célja, hogy amennyiben az alapügyben eljárt bíróság a félnek a kártérítési felelősség általános és különös feltételeinek megléte mellett kárt okozott, akkor a felelősség általános feltételei között a jogellenességet is vizsgálva a bíróság az ilyen módon keletkezett kár megtérítésére kötelezhesse az polgári jogi immunitással nem rendelkező bíróságot. Ezt a tételt az Alkotmánybíróság több ízben kimondta (778/D/2000. és 339/B/2003. AB határozatok), de található példa ennek megfogalmazására a bírósági gyakorlatban is. (PJD 2017.6) Nem szabad elfelejteni azt sem, hogy ezt a tételt még az Európai Unió Bírósága is kifejezetten kimondta a Köbler-ügyben, a bírósági jogkörben okozott károkért való (tag)állami felelősséggel összefüggésben. (C-224/01 Gerhard Köbler kontra Republik Österreich [38] és [40] bekezdés) 
Debreceni Jogi Múhely 2020. (XVII.) 3-4.

Debreceni Egyetem, Állam- és Jogtudományi Kar, Debrecen

(University of Debrecen, Faculty of Law, Debrecen)

DOI 10.24169/DJM/2020/3-4/11

\subsubsection{Kár vagy személyiségi jogsértés}

A bekövetkezett kárt a károsultnak kell bizonyítania. A kár a Ptk. 6:522. \-ban felsorolt bármely módon felmerülhet: vagyonban beállott értékcsökkenés, elmaradt haszon, vagyoni hátrány kiküszöböléséhez szükséges költség is megjelölhető bírósági jogkörben okozott kárként. Kártérités megfizetésére kötelezte például az alperes bíróságot a Fóvárosi Îtélőtábla egy olyan esetben, amikor az alperes bíróság megsértette az idézésre és kézbesítésre vonatkozó szabályokat az előzményügy szlovák alperesével szemben, ezért hiába ítélt meg kártérítést a bírósági jogkörben okozott kár megtérítése iránti per felperesének, a szlovák bíróságok a jogsértést észlelve megtagadták az ítélet elismerését, így a felperes a szlovák bíróság előtti eljárásban pervesztes lett. A Fơvárosi Ítélótábla mindezek alapján az alperes bíróságot a felperesnek a szlovákiai bírósági eljárásban bekövetkezett pervesztessége következtében keletkezett vagyonvesztése összegének megfelelő kártérítés megfizetésére kötelezte. (Fôvárosi Ítélőtábla Pf. 21.115/2014/6.) Egy másik ügyben a Kúria általános kártérités megítélését hagyta helyben, amikor az alperes bíróság tévesen határozott akként, hogy a felperes költségmentessége nem terjed ki az eljárt szakértő költségeire. (LB Pfv. 22.106/2012)

Az 1959-es Ptk-hoz képest az új Ptk. jelentôs módosítása, hogy a vagyoni és nem vagyoni károk megkülönböztetését felváltotta a vagyoni károkozás és a személyiségi jogsértés distinkciója, amely megkülönböztetés az ilyen magatartások szankciójában, a kártérítés és a sérelemdij elkülönülésében is megjelenik. (Lábady, 2016) Abban az esetben tehát, amikor a fél arra alapítja igényét, hogy az ügyében eljáró bíró - bírósági jogkörben eljárva - személyiségi jogában sértette meg, nem kártérítést, hanem sérelemdíjat követelhet, de ilyenkor is a jogi személyiséggel rendelkező bíróság, nem a személyiségi jogot sértő bíró lesz a per alperese a Ptk. 2:51. \(3) bek. alapján. Meg kell jegyezni, hogy a gyakorlat alapján a sérelemdíj megfizetésére kötelezéshez bíróság esetében a bírósági jogkörben okozott kár megtérítéséért való felelősség speciális feltételeinek is teljesülniük kell, önmagában mérlegelési hiba fennállása nem elegendő - kirívóan súlyos jogértelmezési hiba, tévedés lehet a felelősség megállapításának alapja. (BH 2018.141) Az ilyen esetekben viszont fennállhat a veszélye annak, hogy a bírósági jogkörben megvalósított személyiségi jogsértések tárgyában zajló perekben elterjed az a gyakorlat, hogy a bíróságok a „kollégáik” magatartását nem fogják olyan súlyú személyiségi jogsértésnek tekinteni, amely érdemi immateriális hátrányt okozott volna a félnek, így „bagatell igény” címén egyáltalán nem is ítélnek meg sérelemdíjat olyan esetekben sem, amikor az indokolt volna.

\subsubsection{Ok-okozati összefüggés a jogellenes magatartás és a keletkezett kár között}

A kár és a jogellenes magatartás közötti okozati összefüggés, mint a kártérítési felelősség általános feltétele ugyancsak külön vizsgálandó feltétele a bírósági jogkörben okozott károkért megállapítható felelősségnek. Ugyanis hiába állapítható meg a bíróság jogszabálysértő magatartása, valamint az, hogy a félnek kára keletkezett, ha e kettő elem között nincs egy olyan adekvát okozati összefüggés, amely a felelősséget megalapozza, azaz e két feltétel fennállása a bírósági jogkörben okozott károk esetén sem jár együtt szükségszerűen az okozati összefüggés meglétével. Egy közzétett eseti döntésben például a bíróság felróható módon, tévesen állapította meg, hogy egy kft. az üzletrészének árverésen történt értékesítésével a tag személyében történt változás bejelentésére az elővásárlási jog gyakorlása miatt fennálló függó jogi helyzet miatt nem köteles, ezért a változás-bejelentés elmulasztása miatt a törvényességi felügyeleti eljárás lefolytatása szükségtelen. A kft.-ben üzletrészt szerző felperes üzletrész-tulajdonának bejegyzése így nem is történt meg, nem gyakorolhatta az üzletrésze feletti rendelkezési jogát, s nem tudta befolyásolni a kft. ingatlanvagyonának eladását, illetve a társaság felszámolását. A felperes arra hivatkozott, hogy amennyiben a törvényességi felügyeleti eljárás lefolytatásra kerül, az üzletrésze bejegyzésre kerül, ezáltal ő nem szenved el vagyoni hátrányt. A Kúria azonban megállapította, hogy a téves döntés és a felperes perben érvényesített kára között az okozati összefüggés nem volt megállapítható, mivel a törvényességi felügyeleti eljárás kezdeményezése, valamint az eljárás alatti intézkedések önmagukban semmiképp sem eredményezhették volna az üzletrész kft. általi bejegyzését, így a kár bekövetkezése és az alperes bíróság jogellenes magatartása között nem állt fent az adekvát okozati összefüggés. (BH2015.158) 
Debreceni Jogi Műhely 2020. (XVII.) 3-4.

Debreceni Egyetem, Állam- és Jogtudományi Kar, Debrecen

(University of Debrecen, Faculty of Law, Debrecen)

DOI 10.24169/DJM/2020/3-4/11

\subsubsection{Felróhatóság}

A bírósági jogkörben okozott kárért való felelősség feltételei közül (e dolgozat szempontjából különösen) a legnagyobb jelentősége alighanem a felróhatóságnak, illetve annak hiányának, mint a felelősség alóli mentesülés lehetőségének van. A Ptk. 1:4. \szerint a károkozás felróhatósága azt jelenti, hogy a károkozó nem úgy járt el, ahogy az az adott helyzetben általában elvárható. Ahogy Pribula László fogalmaz: „A polgári jogi felelossség zsinórmértéke az elvárbatóság, amelynek biánya a felróhatóság." (Pribula, 2014) Ez a mérce, amelyet a jogalanyok magatartása számára a jogalkotó felállított, egy olyan társadalmi elvárást fogalmaz meg, amelynek konkrét tartalmát az „adott helyzetre” tekintettel a bíróságoknak kell megtölteniük tartalommal. (Fuglinszky, 2015) A bíróságok kárfelelőssége esetében ebből a szempontból egy rendkívül érdekes helyzetet láthatunk. Ugyanis, mivel a bíróságok a jogszabályok értelmezésére hivatott állami szervek (Alaptörvény, 28. cikk), a bírákra vonatkozó szakmai követelmények, szabályok beépülnek a bírák számára adott helyzetben elvárható magatartás fogalmába. (Fuglinszky, 2015) Önmagában ebből az következne, hogy a bíróságok számára a felelősségi mérce rendkívül „alacsonyan” van, azaz a bíróságok részéről kevésbé súlyos jogsértés is megalapozhatja a kártérítési felelősséget, hiszen természetes, hogy a bíróságok szakmai kötelezettségének körébe tartozik a jogszabályok és a joggyakorlat magas szintú ismerete. Mégis, a bírósági jogkörben okozott károkért való felelősség tényállása olyan különleges felelősségi tényállásnak minősül, amely alapján a bíróságok számára támasztott felróhatósági mérce nemhogy alacsonyabb, hanem jóval magasabb, mint más élethelyzetekben eljáró, sőt, mint más szakmai hivatásrendbe tartozó jogalanyok számára. (Fuglinszky, 2015) Hiszen a bírósági jogkörben okozott károk érvényesítésekor az a különleges helyzet áll fent, hogy az eljáró bíróság az alapügyben eljárt bíróság döntése/eljárása jogellenessége kérdésében határoz. A korábban már kifejtettek szerint, ennek a felelősségi alakzatnak a célja az, hogy amennyiben a bíróság jogellenes döntésével vagy eljárásával valamelyik félnek kárt okoz, a kár megtérítésére a bíróság bírói úton kötelezhető legyen.

Fontos tehát rögzíteni, hogy a bírósági jogkörben okozott kár megfizetése iránti per nem egy jogorvoslati eszköz, nem az alapügyben eljárt bíróság végleges, minősített kötőerővel bíró határozata jogerejének megváltoztatására szolgál, erre a célra meghatározott feltételek mellett a rendkívüli perorvoslatok, azaz a perújitás és a felülvizsgálat hivatottak. Ha a bíróságok teret engednének a bírósági jogkörben okozott kár megtérítése iránti pert további jogorvoslatként kezelő szemléletnek, akkor a felek a bíróságok (rájuk nézve kedvezőtlen) döntéseit illetően a végtelenségig indíthatnának pereket, előbb a kártérítési per bírósága által számukra okozott károk megtérítése iránt, majd az újabb kártérítési perben eljárt bíróság ellen, és így tovább. Ennek meg nem engedhetőségét mondta ki a Pécsi Ítélőtábla is egy eseti döntésében. (Pécsi Ítélőtábla Pf. 20.555/2013/5.) Ezzel összefüggésben egyet lehet érteni Vogyicska Petrával abban, hogy akár az is megfontolandó lehetne, hogy törvényi szinten kerüljön kizárásra annak lehetősége, hogy a fél a bírósági jogkörben okozott kár megtérítése iránti perben eljárt bíróság által okozott kárt újabb bírósági jogkörben okozott kár megtérítése iránti perben érvényesítse. (Vogyicska, 2015)

Mindennek fényében, a bírósági gyakorlat kialakított egy olyan feltételrendszert a felróhatóság körén belül, amely biztosítja, hogy a jogkereső felek nem használják a bírósági jogkörben okozott kár megfizetése iránti pereket - hibásan - korábban már elbírált ügyük újbóli elbírálására azáltal, hogy keresetük alapjaként magát a jogerős döntést jelölik meg, nem pedig annak konkrét, számukra kárt okozó részét. Ezt a feltételt a jogirodalom - és az álláspontot átvéve a joggyakorlat is (lásd pl. BH 2009. 325, BDT 2008.1817, BH 2013. 243, Legfelsőbb Bíróság Pf. V. 20.622/1997, Kúria Pfv. III. 20.871/2014) - akként fogalmazta meg, hogy ,az egyedi ügyben hozott döntések jogalkalmazási vagy jogértelmezési tévedései csak akkor járnak kártérítési felelósséggel, ha azok kirívóan súlyosak." (Vékás - Gárdos, 2018; Sopovné, 2009) Több közzétett eseti döntés pedig kifejezetten azt állapította meg, hogy a jogalkalmazási hiba nyilvánvaló és kirívó voltát a bíróság jogellenes magatartása felróhatóságának a kimentése körében kell értékelni. (BDT 2016. 3511, BDT 2017.3650)

A joggyakorlat egyértelmúen abba az irányba mutat, hogy a bíróság által realizált, kirívóan súlyos jogszabály-sértésben vagy jogszabály-értelmezésben megnyilvánuló jogsértést a bíróságok csak nagyon szúk körben állapítják meg. Az egyik leggyakoribb oka a bírósági jogkörben okozott károk megtérítése 
Debreceni Jogi Múhely 2020. (XVII.) 3-4.

Debreceni Egyetem, Állam- és Jogtudományi Kar, Debrecen

(University of Debrecen, Faculty of Law, Debrecen)

DOI 10.24169/DJM/2020/3-4/11

iránti keresetek elutasításának például az, hogy a per alapjául szolgáló döntés/eljárás olyan jogszabály alkalmazásából vagy értelmezéséből eredt (függetlenül attól, hogy az helyesen vagy tévesen történt), amely a bíróságok számára mérlegelési lehetőséget biztosít. Ha ugyanis az adott jogszabályi rendelkezés nem határozza meg szinte teljesen egyértelmúen a bíróságok számára a jogszabály követendő alkalmazási/értelmezési módját, a bíróságok kártérítési felelőssége legtöbbször nem áll meg. A tanulmány szerzőjének álláspontja az, hogy nagyon nehéz összeegyeztetni a bírói függetlenség elvével a bíróságok kárfelelősségének kimondását olyan jogszabályok téves alkalmazásával, illetve értelmezésével összefüggésben, amelyek pont azért hagynak mérlegelési jogkört a bíróságok számára, hogy az adott per tárgyává tett élethelyzetre leginkább megfelelő értelmezést alkalmazzák, és annak megfelelő döntést hozzanak. Elvégre a bírák döntéshozatalát óhatatlanul befolyásolná a tudat, hogy mérlegelési jogkörüket gyakorolva hozott döntésükkel a bíróságnak kárt okozhatnak. Ugyanakkor, mint később ismertetésre kerül, a kirívóan súlyos jogsértés doktrínáját a gyakorlat olyan szigorúan alkalmazta az elmúlt évtizedben, amely indokolttá teszi azt, hogy a felróhatóságról a kártérítési per bírósága az eset összes körülménye alapján döntsön. Fontos tehát adott esetben annak vizsgálata, hogy az adott jogszabályi rendelkezés mennyire volt egyértelmú, és mivel a bíráknak az adott jogkérdés kapcsán irányadó joggyakorlatot is ismerniük kell, az is fontos szempont lehet, hogy az adott jogszabályi rendelkezésnek mennyire alakult ki szilárd, egy irányba mutató gyakorlata. Az adott jogszabály egyértelműsége ellenére téves alkalmazása, illetve értelmezése azonban a kárfelelősséget akkor is megalapozza, ha az adott (rövid idővel korábban hatályba lépett) jogszabályhely vonatkozásában még nem alakult ki egységes bírói gyakorlat. (BH 2009.15. III.)

Látni kell azonban azt, hogy a bírósági gyakorlat nem teljesen következetes abban a tekintetben, hogy a kirívóan súlyos jogsértés doktrínájának terjedelmét hogyan határozza meg. Fel lehet sorolni számos olyan döntést, amelyben nem arról volt szó, hogy a bíróság egy mérlegelést egyáltalán nem megengedó jogszabályt alkalmazott tévesen (pl. egyértelmú illetékes szabályok megsértésével jelöli ki bíróságot a megismételt eljárás lefolytatására) (EBH 2002.751), hanem olyan jellegú hibát vétett az eljárása során, amelyről már nem lehet egyértelmúen kijelenteni, hogy az nem volt kirívóan súlyos. Például a gyakorlat alapján úgy tűnik, hogy a kártérítési perben eljáró bíróságok a beperelt bíróságok által elkövetett számítási hibákat a felróhatóság körén kívül eső hibának tartják. Egy közzétett eseti döntésben a felülvizsgálati fórumként eljáró Kúria a bírósági jogkörben okozott kár megtérítése iránti perben eljárt elsô- és másodfokú bíróság álláspontjától eltérôen nem találta kirívóan súlyos jogsértésnek azt, hogy az alapügyben eljárt bíróság a házastársi közös vagyon megosztása iránti perben az ingatlanforgalmi szakértő véleményét figyelmetlenül nézte át, ebből kifolyólag tévesen határozta meg a házastársakra jutó vagyonrészeket, amelyből fakadóan a felperesnek magasabb összeget kellett megváltási árként fizetnie a volt házastársának. (BH 2013. 243) A Kúria az idézett döntésében hivatkozott egy korábbi ügyre is, ahol a gyermektartás összegének számítási hibából eredố téves megállapítását ugyancsak nem tartotta kirívóan súlyos mulasztásnak. (LB Pfv.21.287/1996/4) Az alapügyben eljárt bíróság kárfelelősségét ettől függetlenül megállapította arra alapozva, hogy a hiba észlelését követően sem hivatalból, sem kérelemre nem került kijavításra. Mindazonáltal álláspontom szerint kérdéses a bíróságok ilyen mérvú számításai hibáinak felróhatóságon kívüli kezelése. Az idézett közzétett eseti döntésben a bíróság hibájával több millió forintnyi kárt okozott a félnek, valamint egy újabb per lefolytatását tette szükségessé, amely ugyancsak jelentős költséget keletkeztetett, immáron az állam számára.

\subsection{Az ügyvédi felelösség hatályos jogszabályi keretei}

Az ügyvédek ügyvédi tevékenységük során okozott károkért való felelősségének szabályait részben a Ptk.-ban, részben az új ügyvédi törvényben, az ügyvédi tevékenységről szóló 2017. évi LXXVIII. törvényben (Üttv.) találjuk. Az új ügyvédi törvény a korábbi törvénytől eltérően nem külön szakaszban rendelkezik az ügyvédek anyagi felelősségéről (1998. évi XI. tv. 10. §), hanem az egyes, ügyvédek által (is) ellátható, és az Üttv. által felsorolt tevékenységek szerint differenciáltan határozza meg az anyagi felelősség korlátait. (T/15371. számú javaslat az Üttv.-ről) Továbbá, az ügyvédi anyagi felelősséggel összefüggésben általában rögzíti, hogy az ügyvédi jogkörben okozott károk és személyiségi jogsértések miatti sérelemdíj követelések fedezetét felelősségbiztosítással kell biztosítani. (2017. évi LXXVIII. 
Debreceni Jogi Múhely 2020. (XVII.) 3-4.

Debreceni Egyetem, Állam- és Jogtudományi Kar, Debrecen

(University of Debrecen, Faculty of Law, Debrecen)

DOI 10.24169/DJM/2020/3-4/11

törvény $14 . \$$ (1) bekezdés) Az tehát expressis verbis már nem szerepel az ügyvédi tevékenységről szóló törvényben, hogy az ügyvéd az általa okozott károkért a Ptk. rendelkezései szerint felel, de ez külön rendelkezés hiányában is így van, tehát meg kell vizsgálni, hogy a Ptk. milyen feltételeket szab a felelősség megállapításához.

Látni kell, hogy az ügyvéd és ügyfele közti kötelmi jogviszony alapvetően különbözhet a bírósági jogkörben történt károkozás esetében a bíróság és a fél közötti jogviszonytól abból a szempontból, hogy míg utóbbi szükségszerűen mindig szerződésen kívüli kötelmi jogviszonyt jelent, addig az ügyvéd és ügyfele között szerződéses - megbízási - jogviszony jön létre, azaz az ügyvéd által végzett tevékenység során ügyfelének okozott károkért nem a deliktuális, hanem a kontraktuális felelősség szabályai lesznek irányadók. Ettől függetlenül, amennyiben az ügyvéd nem az ügyfelének, hanem más személynek okoz kárt ügyvédi tevékenysége során, továbbra is a deliktuális felelósségi szabályokat kell alkalmazni. Az ügyvédek kontraktuális felelősségével összefüggésben szükséges azt is megemlíteni, hogy az Üttv. 28. \(6) bekezdése szerint „A megbizott szerroódésszegésért való felelössége csak egyedileg megtárgyalt szerrzódési feltételben, és csak a kárnak a megbirott kötelezón felelösségbiztositása káreseményenkénti legmagasabb összegét meghaladó része tekintetében korlátozható." Mivel a kötelező felelősségbiztositás összege az új szabályozás szerint tizenöt millió forint kell, hogy legyen, ez a korlátozási lehetôség igen csekélynek mondható.

Alapvető jelentőségű tehát az ügyvédek kárfelelősségének tárgyalásánál, hogy a felelősség megállapítása az ügyfélnek, illetve másnak esetlegesen okozott károk tekintetében nemcsak a deliktuális, hanem a kontraktuális felelősség szabályai szerint is történhet, amelynek elvi alapja is különbözik a deliktuális felelôsségétől. Az új Ptk. hatályba lépésével a deliktuális és a kontraktuális felelôsség egymástól elválasztásra került, az új kódex a kontraktuális felelősséget objektív alapra helyezte. (Kemenes, 2017) Azaz a szerződéses kötelezettségek megszegése miatti felelósség felróhatóságtól független lett, a felelősség megállapításánál nem kell vizsgálni a károkozó felróhatóságát. (Fuglinszky, 2015) Ez a szemlélet alapvetően érthető: a kontraktuális felelősség felmerülésekor a kárt okozó magatartás egy olyan szerződéses kötelezettség megszegését jelenti, amelyet a kárt okozó, szerződő fél a saját helyzetének és érdekeinek mérlegelésével, önként vállalt magára.

A kontraktuális felelősség esetén adott tehát a helyzet, hogy amennyiben a felek között szerződés jön létre, a szerződésszegésből eredő károk megtérítését a károsult a Ptk. 6:145. \alapján a kontraktuális felelősség szabályai szerint követelheti, méghozzá akkor is, ha egyébként a károkozó magatartása a deliktuális felelősségét is megalapozza. Ugyanakkor, a Ptk. 6:59. \$(2) bekezdés alapján a felek a Ptk. eltérő rendelkezése hiányában a szerződéseknek a felek jogaira és kötelezettségeire vonatkozó szabályaitól eltérhetnek. Ezen, a szerződésszegésért való felelősség kizárását vagy korlátozását megengedő rendelkezés általános korlátját a Ptk. 6:152. \akként fogalmazza meg, hogy a szándékos, az emberi életet vagy egészséget károsító szerződésszegésért való felelősség kizárása semmis. Az ügyvédi megbízás esetén mindezt az eddigiek alapján csupán az Üttv. már korábban említett 28. \(6) bekezdése alapján kell kiegészíteni, amely elôírja, hogy a megbízott szerződésszegésért való felelőssége csak a kárnak a kötelezô felelősségbiztosítás legmagasabb összegét (15 millió Ft) meghaladó része tekintetében korlátozható.

Mindazonáltal nagyon fontos felhívni a figyelmet arra a vizsgált téma szempontjából rendkívül fontos tényre, hogy a megbízási típusú szerződéseknél a kontraktuális felelősség objektív oldala nem tud úgy érvényesülni, mint más szerződéstípusoknál. Ugyanis a megbízási típusú szerződések gondossági kötelmet hoznak létre: a megbízott nem eredmény szolgáltatását vállalja, hanem azt, hogy a rábízott feladatot megfelelő, kellő gondossággal ellátja. (Fuglinszky - Tőkey, 2018) Ebből fakadóan a megbízási típusú szerződésekből származó kötelezettségek megszegéséért való felelősség megállapítása nem lehetséges tisztán objektív alapon, mivel a szerződésnek az általa keletkeztetett kötelemből eredően fogalmi eleme a gondosság, amelynek a gyakorlati megnyilvánulása az, hogy a megbízottnak a tôle elvárható gondossággal kell eljárnia a rábízott feladat teljesítése során. Ha pedig a megbízottól elvárható gondosságot vizsgáljuk, már a felróhatóság területén járunk, azaz kijelenthető, hogy a megbízási típusú szerződések esetében a kontraktuális kárfelelősség objektív alapja, azaz a szerződésszegés maga a felróható magatartás, így, ahogy Kemenes is hangsúlyozza, az ilyen típusú szerződéseknél a felelősség objektív és szubjektív eleme egybeesik, tehát a Ptk. 6:142. \szerinti objektív felelősség itt nem 
Debreceni Jogi Múhely 2020. (XVII.) 3-4.

Debreceni Egyetem, Állam- és Jogtudományi Kar, Debrecen

(University of Debrecen, Faculty of Law, Debrecen)

DOI 10.24169/DJM/2020/3-4/11

alkalmazható. (Kemenes, 2017)

Mindezek - a Ptk. és az Üttv. szabályai - alapján az ügyvédi kárfelelősség feltételeit a következők szerint lehet megállapítani. Amennyiben ügyvédi tevékenység ellátása során az ügyvéd tevékenységével vagy mulasztásával olyan személynek okoz kárt, akivel nem áll szerződéses jogviszonyban, úgy a Ptk. deliktuális felelősségi feltételeinek fennállását kell vizsgálni. Az ügyfeleknek, mint megbízóknak okozott károk esetén pedig a kiindulópont az, hogy a korábban már hivatkozott Ptk. 6:145. \alapján a jogosult akkor is a kontraktuális felelősség szabályai szerint érvényesítheti a kártérítési igényét a károkozóval szemben, ha a károkozó magatartás a károkozó deliktuális felelősségét is megalapozná, ezért az ügyvédi megbízási szerződés alapján az ügyvéd által az ügyfélnek okozott kárra a kontraktuális felelősség szabályait kell alkalmazni.

A kár keletkezése, valamint a károkozó magatartás és a keletkezett kár közötti ok-okozati összefüggésre a bírósági jogkörben okozott károkért való felelősség kapcsán elmondottak megfelelően irányadók: kárként ugyanazok a kárelemek merülhetnek fel, valamint az ügyvédi kárfelelósség esetén is adekvát kauzalitási kapcsolatnak kell fennállnia a károkozó - jelen esetben szerződésszegó - magatartás és a keletkezett kár között. Az ügyvéd által okozott károk esetén is irányadó tehát, hogy a jogsértő magatartás és a keletkezett kár közötti okozati összefüggésnek közvetlennek kell lennie. (EBH 2006.1410) Az ok-okozati összefüggéssel összefüggésben nem alapozza meg például az ügyvéd kárfelelősségét, ha az ingatlan-nyilvántartásba bejegyzendő jogra vonatkozó szerződés készítése során a szerződő féltől nem szerezte be a személyi azonosítóját, ha a változás bejegyzése nem ezen ok miatt maradt el. (BDT 2009.1984) A felelősség megállapításához azt kell bizonyítani, hogy a károkozó, jelen esetben az ügyvéd, szerződésszegô magatartást tanúsított, azaz a szerződésből eredő kötelezettségét nem szerződésszerűen teljesítette. (Fuglinszky, 2015) Ez az ügyvédi megbízás esetében azt jelenti, hogy a károsultnak azt kell bizonyítania, hogy az ügyvéd nem tanúsított kellő gondosságot a megbízás teljesítése során. Ennek a feltételnek a teljesülése viszont a korábbiakban elmondottaknak megfelelóen nem egy objektív elem, nem lehet a károkozó ügyvéd felróhatóságának vizsgálata nélkül megállapítani, hogy a szerződéses kötelezettségét megszegte, hiszen a rábízott feladat kellő gondossággal való ellátását nem lehet objektív zsinórmértékhez kötni, azt, hogy az adott esetben az ügyvéd kellő gondossággal járt-e el, mindig az eset összes körülményeire tekintettel kell vizsgálni.

A felelősség alóli kimentés ugyanakkor a kontraktuális felelősség esetében jóval szigorúbb szabályok mellett lehetséges. A Ptk. 6:142. \szerint a felelősség alóli kimentéshez az szükséges, hogy a károkozó bizonyítsa, hogy a szerződésszegést ellenőrzési körén kívül eső, a szerződéskötés időpontjában előre nem látható körülmény okozta, valamint nem volt elvárható, hogy a körülményt vagy a kárt elhárítsa. Meg kell azonban jegyezni, hogy az új Ptk. által bevezetett, igen szigorúnak mondható kimentési szabálynak az ügyvédi megbízásnál nincs akkora hatása, mint más típusú szerződéseknél, hiszen, ha az ügyvéd a tôle elvárható (fokozott) gondossággal látta el a rábízott feladatot, nem valósul meg szerződésszegés, s ahogy Fuglinszky fogalmaz: „az ügy a kimentésig el sem jut”. (Fuglinszky, 2015) Kijelenthető tehát, hogy a szigorú kimentési szabálynak ebben a körben általánosságban nincs különös jelentősége. Ugyanakkor talán mégis érdemes itt utalni egy olyan, az ügyvédi megbízás kapcsán különlegesebbnek mondható esetkörre, amely álláspontom szerint a gondosság és a kimentés témakörét is érinti. A Ptk. 6:273. \(3) bekezdése alapján, a megbízó célszerútlen vagy szakszerútlen utasítása esetén a megbízott a szerződéstől elállhat, azt felmondhatja, vagy a megbízó kockázatára az utasítást teljesítheti, kivéve, ha jogszabály vagy hatósági határozat megsértésére vezetne. Ebből következően egyet lehet érteni azzal az állásponttal, hogy az ügyvédi megbízás esetében az ügyvéd fokozott gondossága abban is meg kell, hogy nyilvánuljon, hogy a megbízója célszerútlen vagy szakszerútlen utasításának teljesítésével okozott kár esetén a felelősség alól csak akkor mentesülhet, ha az ügyvédi tevékenységre irányadó szabályokat nem sérti az eljárása. (Sándor - Szűcs, 2014) Elvégre az ügyvédnek a rá irányadó jogszabályok és kamarai szabályzatok előírásainak való megfelelése akkor is prioritást kell, hogy élvezzen a megbízó utasításához képest, ha a megbízást az ügyfél érdekeinek elsődlegessége alapján kell ellátnia. Ugyan egészségügyi szolgáltatóval összefüggésben (amely szintén megbízott volt az adott jogviszonyban), de egy közzétett eseti döntés konkrétan meg is fogalmazta, hogy a szakmai szabályoknak való megfelelés a felróhatóság körében vizsgálandó. (BDT 2007.1689) Ez pedig - tekintve, hogy az egészségügyi szolgáltatók és a páciensek viszonyában is gondossági 
Debreceni Jogi Múhely 2020. (XVII.) 3-4.

Debreceni Egyetem, Állam- és Jogtudományi Kar, Debrecen

(University of Debrecen, Faculty of Law, Debrecen)

DOI 10.24169/DJM/2020/3-4/11

kötelemről beszélhetünk - az ügyvéd és ügyfele közti kárfelelősségi viszonyban is alkalmazandó.

Látható tehát, hogy az ügyvédi megbízás esetében a szerződésszegés, mint a kontraktuális felelôsség főszabály szerint objektív feltétele és a kontraktuális felelősségnél fószabály szerint figyelembe nem is veendő felróhatóság vizsgálata egybe esik. Az ügyvédek ügyvédi tevékenységük során okozott kár megtérítéséért való felelôssége tekintetében a bírósági jogkörben okozott kár megtérítéséért való felelősséghez hasonlóan a bírói gyakorlatra vár az a feladat, hogy a megbízási szerződésből eredő gondosság felróhatósági alapú követelményének tartalmát megállapítsa.

Mint már korábban említésre került, annak vizsgálatánál, hogy az ügyvéd a rábízott feladatának ellátása során kellő gondossággal járt-e el, vizsgálni kell a károkozó felróhatóságát is. A felróhatóság vizsgálatánál a Ptk., az Ütttv. és az ügyvédi kamarai szabályzatok ügyvédi tevékenységet érintô szabályai nyújthatnak iránymutatást a bíróságoknak abban a tekintetben, hogy az alperes ügyvéd kellő gondosságot tanúsított-e az adott esetben vagy sem. A Ptk. vonatkozó szabályainak elemzése mellett, szükséges azonban még röviden utalni az Üttv. és a Magyar Ügyvédi Kamara szabályzataira is. Az Üttv. az egyes ügyvéd által végezhetô tevékenységekre vonatkozó rendelkezéseket külön-külön tünteti fel. Így például a jogi képviselet ellátása, valamint az okiratszerkesztés során az Üttv. eloórja, hogy az ügyvéd köteles megtagadni a megbízó utasításának teljesítését, ha annak teljesítése jogszabályba ütközne vagy jogszabály megkerülésére irányul, és az okirati ellenjegyzéssel kapcsolatban is meghatároz egyes szabályokat. Az Üttv. által felsorolt ügyvédi tevékenységekkel összefüggésben a Magyar Ügyvédi Kamara szabályzatai és tájékoztatói is iránymutatást jelenthetnek. (lásd pl. 11/2017. (XI. 20.) MÜK szabályzat)

Figyelembe véve, hogy az ügyvédi tevékenység körében jóval többfajta olyan cselekmény végezhető, amivel összefüggésben az ügyfél kárt szenvedhet, mint a bíróságok esetén, ezért az ügyvédi károkozás felróhatóságának témakörében lényegesen több tevékenységhez kapcsolódó esettel találkozhatunk a bírósági jogkörben okozott károk megtérítése iránti perekhez képest. A Kúria egy eseti döntésében például megállapította annak az ügyvédnek az ügyfele irányában fennálló kárfelelősségét, akinek az ügyfele azért nem tudta megszerezni egy ingatlan tulajdonjogát, mert az alperes ügyvéd egy olyan szerződést szerkesztett, amely nem felelt meg a felek akaratának, azaz „nem volt alkalmas a megbízói célnak megfelelő joghatás kiváltására", mivel nem vette figyelembe, hogy a kérdéses ingatlanon jelzálogjog áll fent. (Kúria Pfv. 21.816/2013) Ebben az esetben tehát a Kúria az ügyvédnek felróható szerződésszegésének tekintette azt, hogy nem a megbízásban foglalt célnak megfeleló, arra alkalmas szerződést szerkesztett, ezt az álláspontot pedig az újabb gyakorlatban is fenntartotta. (lásd Kúria Pfv. 20.747/2016, Kúria Pfv. 21.456/2016 és Kúria Pfv. 20.158/2017) Fontos ugyanakkor megjegyezni, hogy önmagában az, hogy az ügyvéd által szerkesztett és ellenjegyzett adásvételi szerződés alapján a vevő tulajdonjogát nem jegyzik be az ingatlan-nyilvántartásba, nem alapozza meg az ügyvéd kárfelelősségét, ha egyébként nem megállapítható, hogy az ügyvéd megfelelő, kellő gondossággal járt el, hiszen a megbízási szerződés alapján nem eredménykötelem jön létre, tehát nem feltétlenül vezet a megbízási szerződés szerinti cél megvalósulásának elmaradása az ügyvéd felelősségének megállapítására. (BDT 2009.1948) Egy másik esetben az ügyvéd kártérítési felelősségét a Kúria az ügyféllel ingatlan adásvételi szerződést kötő személlyel szemben mondta ki. (Kúria Pfv. 20.065/2012) $\mathrm{Az}$ ügyvéd úgy szerkesztette meg és jegyezte ellen az adásvételi szerződést, hogy tudta vagy tudnia kellett, hogy ügyfele nem volt tulajdonosa az eladni kívánt ingatlannak, mivel az ingatlan ügyfele általi megvásárlásakor az ügyfele tulajdonjog bejegyzése iránti kérelme csak széljegyen szerepelt, azaz vitán felül áll, hogy magatartása felróható volt.

A bíróság az ügyvédi elvárhatósági mércét igen magasra helyező döntést hozott egy olyan közzétett eseti ügyben, ahol az ügyvéd károkozó magatartása abban nyilvánult meg, hogy nem hívta fel az ügyfele, mint egy ingatlan adásvételi ügylet eladójának figyelmét arra, hogy a vevô cég felszámolás közeli helyzetben van, ezért az ügylet meghiúsulásából származó károk megtérítésére kötelezte. (BH 2016.244) A bíróság a BH 2000.198 számon közzétett eseti döntés tartalmát alkalmazta a konkrét esetre, amely alapján megállapította, hogy a felperes által megbízott ügyvédnek, akinek a gondatlan mulasztása tette lehetővé a vevő szándékos károkozását, a kárért akkor is fennáll a vevővel egyetemleges felelőssége, ha akarategység a károkozás tekintetében köztük nem állt fent. Jelen döntés jelentősége az ügyvédi anyagi felelősség szempontjából tehát akként ragadható meg, hogy az újabb 
Debreceni Jogi Műhely 2020. (XVII.) 3-4.

Debreceni Egyetem, Állam- és Jogtudományi Kar, Debrecen

(University of Debrecen, Faculty of Law, Debrecen)

DOI 10.24169/DJM/2020/3-4/11

bírósági gyakorlat szerint az ügyvéd nemcsak saját kelló gondosságának biztosítása, hanem az ügyfele szempontjából releváns kockázatok minimalizálása, vagy legalábbis ügyfelének a kockázatokról való tájékoztatása biztosításáért is felelősséggel tartozik.

A célzott joghatás kiváltására alkalmas okirat szerkesztésének elmulasztása nemcsak a szerződésekkel összefüggésben eredményezheti az ügyvéd kártéritési felelősségének megállapítását. Egy korábbi közzétett eseti döntésben a bíróság azért kötelezett egy ügyvédet az ügyfelének okozott károk (jelen esetben az ügyvédnek kifizetett megbízási dijat követelték) megfizetésére, mert az ügyvéd által szerkesztett cégbejegyzés iránti kérelem a hiányai miatt alkalmatlan volt a célzott joghatás, azaz a gazdasági társaság bejegyzésének kiváltására. (BDT 2007.1564) Érdemes megemlíteni azt az újabb kúriai döntést is, amelyben a bíróság egy még az 1959-es Ptk. alapján létrejött megbízási szerződés alapján egy ingatlan-adásvételi szerződést szerkesztő ügyvédet nem vagyoni kártérítés megfizetésére kötelezett. (Kúria Pfv. 20.956/2017) A döntés indokául az szolgált, hogy az eredeti ingatlan adásvételi szerződést az ügyvéd úgy szerkesztette meg, hogy nem vette figyelembe, hogy az ügyfelével szerződést kötő eladó tulajdonjoga csak széljegyként volt bejegyezve. Így mikor ügyfele az ingatlant tovább akarta értékesíteni, ezt nem tudta joghatályosan megtenni, a korábbi „tulajdonostól” pedig a kifizetett vételárat végrehajtás útján sem tudta behajtani, amelynek következtében egy több mint 15 évet felölelő pereskedés kezdődött, a nem vagyoni kártéritést pedig az ezzel összefüggő pszichés megterhelésre tekintettel ítélte meg a bíróság. Különösen érdekes ez a döntés annak fényében, hogy még a Kúria sem látott kivetnivalót a másodfokú bíróság azon érvelésében, hogy az ügyvéd eredeti szerződésszegő magatartása és a keletkezett nem vagyoni (ma: személyiségi jogi) sérelem között csak részben áll fent okozati összefüggés, amelyet a korábban hivatkozott EBH 2006.1410 számon közzétett elvi határozatban még az igényérvényesítést kizáró körülményként értékelt a Legfelsôbb Bíróság. (Kúria Pfv. 20.956/2017, [24] bekezdés)

Szintén gyakori, hogy az ügyvédekkel szemben a pernyertesség esélyének elvesztésére hivatkozással indítanak kártérítés megfizetése iránti pert. Az ilyen, és ehhez hasonló esetek kapcsán érdemes szót ejteni az ún. árnyékperek problematikájáról is. Az árnyékperekkel szemben, azaz az olyan perekben, ahol a felek olyan határidó elmulasztását jelölik meg a kárt okozó felróható magatartásként, amelynek eredményeként az ügyfél elveszítette a pernyertesség esélyét, a joggyakorlat alapvetően az 1990-es évektől kezdődően elutasító volt, a bíróságok az ok-okozati összefüggés hiányában nem találták az ügyvédekkel szembeni kárigényeket megalapozottnak. (Csöndes, 2017) Ettől függetlenül érdemes megemlíteni, hogy találni olyan közzétett eseti döntést is, ahol a bíróság kifejezetten kimondta, hogy mivel az alapperben az ügyfél fellebbezése nem került elbírálásra, a kártérítési per bíróságának kell érdemben elbírálnia a fellebbezést. (BDT 2002.580) Molnár Levente részletesebb elemzés alá véve a problémakört, megállapította, hogy a 2010-es évek legelejétől kezdve az figyelhető meg, hogy a bíróságok az ügyvédekkel szemben indított kártérítési perekben nem vizsgálják meg azt, hogy az ügyvédi múhiba hiányában az ügyfél pernyertes lett volna avagy sem. (Molnár, 2013) Hivatkozik egy 2009-es Legfelsőbb Bíróság előtti ügyre, amelyben a felperes ügyfél arra alapította a korábban jogi képviselőjeként eljárt ügyvéd elleni kártéritési igényét, hogy az nem terjesztett elő érdemi ellenkérelmet, amelynek következtében pervesztes lett. (a LB Pfv. 21.129/2009. számú ügyet Molnár ismerteti, lásd Molnár, 2013) Az ügyvéd felelősségének megállapításához az ok-okozati összefüggés is hiányzott, de a Legfelsőbb Bíróság kiemelte, hogy annak fennállása esetén sem lehetett volna vizsgálni azt, hogy érdemi védekezés előterjesztése esetén az alapügy hogyan alakult volna. Ugyanerre az álláspontra helyezkedett a Legfelsőbb Bíróság egy másik, Molnár által idézett 2011-es döntésben, ahol az árnyékper lefolytatásának tilalmát a fellebbezési határidő elmulasztásával összefüggésben mondta ki a bíróság, megjegyezve ugyanakkor, hogy a jogorvoslathoz való jog sérelmére tekintettel az ügyvéd nem vagyoni kártérítés megfizetésére köteles. (LB Pfv. 20.928/2010 (BH 2012.90 szám alatt közzétéve)) A hivatkozott tanulmány fő tárgyát képező, BH 2013.89 szám alatt közzétett döntésben a Kúria egy olyan esetet bírált el, amelyben az ügyvéd mulasztása a Be. szerinti kártalanitás iránti igény határidőben történő előterjesztésének elmulasztásában állt. (BH 2013.89) Ez a döntés hasonlóságot mutat az előző döntéssel abban is, hogy ugyan a Kúria nem látta bizonyítottnak a kár és a jogsértő magatartás közötti okozati összefüggést, mivel nem lehetett volna az első- és másodfokon eljárt bíróságoknak feltételezések alapján dönteni arról, hogy az érdemi védekezés előterjesztésével és a kért bizonyítás lefolytatásával az eljárás milyen eredménnyel zárult volna, az ügyfél jogorvoslathoz való jogának 
Debreceni Jogi Múhely 2020. (XVII.) 3-4.

Debreceni Egyetem, Állam- és Jogtudományi Kar, Debrecen

(University of Debrecen, Faculty of Law, Debrecen)

DOI 10.24169/DJM/2020/3-4/11

sérelme miatt nem vagyoni kártérítés megfizetésére kötelezte az ügyvédet. Ez a többször is alkalmazott megoldás azonban csekély kompenzációt jelent az ügyfélnek, azaz a kártérítési per felperesének, hiszen bár az okozati összefüggés hiánya miatt valóban nem lehet az árnyékper lefolytatása nélkül megállapítani az ügyvéd kárfelelősségét, a helyzet mégis az, hogy az ügyfél a jogorvoslat elmulasztása révén a pernyertességének esélyét valóban elvesztette, amely adott esetben azt eredményezheti, hogy a megítélt nem vagyoni kártérítés (ma már sérelemdíjról lenne szó) összege elenyésző ahhoz az összeghez képest, amelyhez egy sikeres jogorvoslat igénybevételével juthatott volna. Ugyanakkor ebben az esetben az árnyékperek lefolytatása az alapügyben hozott döntés jogerejét már olyan szinten kikezdi, amely álláspontom szerint nem teszi lehetővé, hogy a kártérítési per bírósága az alapügyben elmaradt jogorvoslati eljárást lefolytassa.

\section{A bíróságok és az ügyvédek kárfelelősségének egybevetése az elvárhatóság szempontjából}

Látható tehát, hogy a bírósági jogkörben okozott károk megtérítése, valamint az ügyvédekkel szembeni kártérítési igények sikeres érvényesíthetôsége között jelentôs különbség tapasztalható. A bíróságok perlése a bírósági jogkörben okozott károk megtérítése iránt az évtizedes gyakorlat alapján rendkívül nehezen teljesíthetô feltételekhez kötött.

Az első ilyen feltétel a gyakorlat által kimunkált kirívóan súlyos jogsértés doktrínája, vagyis az, hogy a bíróságok részéről az egyszerú jogszabálysértések önmagukban nem alapozzák meg a bíróság kártérítési felelősségét, ahhoz kirívóan súlyos jogalkalmazási, illetve jogértelmezési hibára, tévedésre van szükség. A bemutatott joggyakorlatból egyértelmúen megállapítható, hogy a bíróságok nagyon szúken határozzák meg a kirívóan súlyos jogsértések körét.

A bírósági jogkörben okozott károk érvényesítésével szembeni második jelentős „védvonalat” az jelenti, hogy a bíróságok az esetek túlnyomó többségében még mindig tartják magukat ahhoz az állásponthoz, hogy a bírósági jogkörben okozott károk megtérítése iránti igények alapjául nem szolgálhat a jogerős ítélet tartalma, amelyet Fuglinszky a jogerős ítélet tartalmi immunitásának követelményének hív. (Fuglinszky, 2015) Ezen feltétel kapcsán a bírósági jogkörben okozott kár megtérítése kérdésében döntő bíróságok csak akkor látszanak engedékenységet mutatni, ha a jogalkalmazási, illetve jogértelmezési tévedés vagy hiba nem a jogerős döntés érdeméhez kapcsolódik, hanem ha egy jól elhatárolható, önálló jogszabálysértésről van szó. A bírósági gyakorlatban ezt az elvet azzal támasztják alá, hogy a tartalmi immunitás elvének hiányában a jogkeresők óhatatlanul úgy tekintetének a bírósági jogkörben okozott károk megtérítése iránti perekre, mint egy olyan további jogorvoslati lehetőségre, amelyben az eljáró bíróság már elbírált (és meg nem ítélt) igényüket újból elbírálhatja. Ez pedig ahhoz vezethetne, hogy a jogintézményt tömegesen használnák a jogkeresők a rendeltetésétől eltérô célra, amely valóban egy elkerülendő jelenség. Ugyanakkor fontos leszögezni, hogy a bírósági jogkörben okozott károk megtérítéséért való felelősségnek az új Ptk.-ban való kifejezett kimondása is azt indokolja, hogy az alakzat ne kerüljön kiüresítésre azáltal, hogy a gyakorlat a sikeres igényérvényesítéshez olyan feltételeket szab, amelyek teljesíthetősége igencsak kérdéses és jogilag is megkérdőjelezhetô. Ráadásul, az alapügyben eljárt bíróság vagy bíróságok jogszabálysértő jogértelmezése vagy jogalkalmazása által okozott károk az alapügy jogorvoslati eljárásában nem is mindig orvosolhatóak, akár még a Kúria általi felülvizsgálati eljárásban sem, elvi szinten pedig még az sem zárható ki, hogy pont a felülvizsgálati eljárás során történik olyan károkozás, amelynek orvoslására a bírósági jogkörben okozott károk megtéritése iránti per szolgálhat, ezért a bírósági kárfelelősségi alakzatra napjainkban is szükség van. (Pákozdi, 2015) A jogerős ítéletek tartalmi immunitásának álláspontom szerint legnagyobb hiányosságára Pákozdi mutatott rá egy korábbi tanulmányában. A kiindulópont az, hogy az anyagi jogerőhatás törvényi fogalmát a Polgári Perrendtartásról szóló 2016. évi CXXX. törvény 360. \-a alapján három elem alkotja: a fél-, jog- és tényazonosság. Pákozdi Farkas Józsefre hivatkozva helyesen írja, hogy ezen három feltétel közül a jogazonosság - amelynek a tartalmi immunitás szempontjából talán a legnagyobb jelentősége van - fennállását a kereseti kérelem vizsgálata alapján lehet meghatározni. (Pákozdi, 2011) Azaz, ha a fél a bírósággal szembeni kártérítési igényének érvényesítésére irányuló kereseti kérelmében ugyanazt a jogalapot jelöli meg, mint az alapperben, akkor valóban fennáll a jogazonosság, s az alapügyben hozott ítélet jogereje megakadályozza (és meg is kell, 
Debreceni Jogi Múhely 2020. (XVII.) 3-4.

Debreceni Egyetem, Állam- és Jogtudományi Kar, Debrecen

(University of Debrecen, Faculty of Law, Debrecen)

DOI 10.24169/DJM/2020/3-4/11

hogy akadályozza), hogy a már jogerősen elbírált kereseti kérelmet egy másik bíróság újból elbírálja. Nem lehet elmenni szó nélkül amellett a gondolat mellett sem, hogy amennyiben a bíróságok a kártérítési igények érvényesíthetőségét ilyen szűk keretek közé szorítják, az már nem a jogorvoslathoz való jog, hanem az Alaptörvényben biztosított tisztességes eljáráshoz való jog sérelmét is felvetheti. (Pákozdi, 2011)

A harmadik feltétel, amelyre Fuglinszky is felhívja a figyelmet, hogy a bíróságok azt is elvárják, hogy a fél olyan érvre hivatkozzon a kártérítési perben, amelyre már az alapügyben is hivatkozott. (A Pfv. 21.974/2012 számú kúriai döntésre Fuglinszky hivatkozik; Fuglinszky, 2015) Ezen három feltétel együttes teljesítésének elvárása mellett álláspontom szerint egyáltalán nem meglepőek a bírósági jogkörben okozott károk megtérítése iránti perek statisztikái. Az új Ptk.-t megelőző évtizedben is $90 \%$ körül mozgott azon ügyek aránya, amelyekben a bírósági jogkörben okozott károk megtéritése iránti perekben az alperes bíróságot mondták ki pernyertesnek. (Borbás, 2014) Ez az arány azóta csak még magasabbra, 95 és 99 \% közé nőtt. (lásd, OBH elnöki beszámolók 2014-2018)

Az ügyvédekkel szemben érvényesített kártérítési igények kapcsán ugyanakkor a bíróságok részérôl nem tapasztalható ez a szigorú elvárásrendszer. A joggyakorlat következetesen érvényesíti azt az elvet, hogy az ügyvédi károkozás felróható minden olyan magatartás esetén, amikor az ügyvéd a tevékenysége során nem olyan fokozott gondossággal jár el, amely szükséges az ügyfele jogainak és jogos érdekeinek érvényesítéséhez. Igaz ez a határidők, a tájékoztatási kötelezettség vagy a kellő körültekintés elmulasztásában megnyilvánuló károkozások tekintetében is. Ugyanakkor a jogerős ítélet tartalmi immunitásának elve itt is érvényesül, amely az ügyvédi kárfelelősség szempontjából abban nyilvánul meg, hogy a bíróságok a legtöbb esetben nem folytatnak le árnyékpereket annak megállapítására, hogy az ügyvéd által elmulasztott jogorvoslat előterjesztésének elmulasztása hiányában az ügyfél pernyertes lett volna, avagy sem. Az ilyen esetekben a bíróságok az ügyvéd kárfelelősségét okozati összefüggés hiányában nem állapítják meg.

A bíróságok és az ügyvédek kárfelelósségének megállapítása során alkalmazott felelősségi mérce különbségének elemzése több oldalról is lehetséges. Szükséges leszögezni, hogy alapvetően két olyan hivatásrend tevékenységéért való felelősségről van szó, amelyek tevékenységének alapja egyaránt a jogszabályok, és a joggyakorlat megfelelő ismerete. Az általuk kifejtett tevékenység azonban rendkívül különböző. A bíróságok az állam igazságszolgáltatási monopóliummal felruházott szervei, amelyek feladata a jogszabályok értelmezése alapján a felek bíróság elé vitt jogvitái végleges eldöntése. Ezzel szemben az ügyvédek az Üttv. 1. S-ának megfelelően csak közremúködnek az igazságszolgáltatásban, és ügyfeleik jogainak és jogos érdekeinek érvényesítése érdekében lelkiismeretesen, legjobb tudásuk szerint kötelesek eljárni, azonban ezt jóval többféle tevékenység keretében teszik, mint a bíróságok. Peres eljárásban ellátott jogi képviselet, okirat-szerkesztés, ellenjegyzés, nemperes eljárások során ellátott jogi képviselet során okozott károkért is kártérítési igényt lehet érvényesíteni az ügyvéddel szemben, erre tekintettel pedig az Üttv. a korábban elmondottaknak megfelelően felelősségbiztosítási kötelezettséget is előír az ügyvédek számára.

Nagy különbség van abban is, hogy a fél és a bíróság vagy az ügyvéd között létrejövő kötelmi jogi jogviszonynak mi az alapja. A bírósági jogkörben okozott károk esetén szerződésen kívüli jogviszonyról és szerződésen kívül okozott kárról, míg az ügyvéd-ügyfél viszonylatban szerződéses jogviszonyról és szerződésszegéssel okozott károkról beszélhetünk. Ily módon a felelôsség alapja a felelősség két címzettje esetében teljesen különbözhet, amely a kártérítési felelősségnél alkalmazott felróhatósági mércében is szükségszerúen meg kell, hogy mutatkozzon. Az új Ptk. rendszerében a deliktuális károkozástól határozottan elválasztott szerződésszegéssel okozott kár esetében a kiinduló gondolat az, hogy a szerződésszegéssel kárt okozó fél saját körülményeinek, kockázatainak tudatában kötött szerződést, és vállalta magára az abból fakadó kötelezettségeket. Ez a Ptk. rendszerében a kontraktuális károkozás tekintetében objektív, felróhatóságtól független felelősség kimondásában nyilvánult meg. Ugyanakkor, mint korábban kifejtésre került, az ügyvédi megbízás - gondossági kötelemről lévén szó - esetében a felróhatóság mégis vizsgálandó, mivel a gondossági kötelmek esetében a szerződésszegés éppen az elvárható gondosság felróható elmulasztása. Látható tehát, hogy a felelősség megállapításához a felelősség mindkét címzettje esetében vizsgálandó, hogy a károkozó magatartásuk felróható volt-e vagy sem, ezért tisztán azon az alapon, hogy a bírósági jogkörben 
Debreceni Jogi Múhely 2020. (XVII.) 3-4.

Debreceni Egyetem, Állam- és Jogtudományi Kar, Debrecen

(University of Debrecen, Faculty of Law, Debrecen)

DOI 10.24169/DJM/2020/3-4/11

okozott károk esetén deliktuális, míg az ügyvédi károkozás esetén kontraktuális jogviszonyról van szó, nem indokolható az elvárhatósági mércében mutatkozó különbség.

Arra, hogy a felróhatóság körét a bíróságok esetében a kártérítési perben eljáró bíróságok jóval szúkebben határozzák meg, több magyarázat is adható. A joggyakorlatban elsősorban az ítéletek Bszi. szerinti véglegességére és minősített kötőerejére hivatkoznak, amikor amellett érvelnek, hogy a már jogerősen eldöntött jogvitában hozott ítélet tartalmára nem alapítható kártérítési igény, mivel az a jogerős ítélet jogellenes felülbírálatát eredményezné. Ez az érv álláspontom szerint el is fogadható azokban az esetekben, amikor valóban nem a konkrét károkozó magatartást jelölik meg a kártérítés alapjául szolgáló magatartásként, de amikor a kártérítési per alapjául szolgáló döntés (amely nemcsak itélet, hanem például a cégbíróságnak a gazdasági társaság bejegyzését elutasító végzése, az ítélet hivatalbóli kijavításáról való döntés elmulasztása, stb. is lehet) teljes tartalmától elhatárolható módon, az annak meghozatala során kifejtett károkozó magatartásra történik hivatkozás, már nem.

A bíróságok ráadásul erre a gondolatra alapítva, a jogerôs bírósági döntéseket „védelmezendô” a kirívóan súlyos jogsértés doktrínáját is kialakították, amelynek értelmében csak a kirívóan súlyos jogértelmezési, illetve jogalkalmazási hiba alapozza meg a bíróságok kárfelelősségét. A kirívóan súlyos jogsértések körét - amelyet a felróhatóság körében kell vizsgálnia a kártérítési per bíróságának - pedig a bíróságok a bemutatott gyakorlat alapján láthatóan nagyon szúken értelmezik. Kirívóan, súlyosan jogszabálysértő tévedésnek vagy hibának általában csupán azon magatartások minősülnek a gyakorlat szerint, amelyek mérlegelést nem igénylő, egyértelmú jogszabályokhoz kötődnek. A mérlegelést engedő jogszabályok értelmezésével vagy alkalmazásával okozott károkkal szemben a gyakorlat továbbra is elutasító, amellyel annyiban egyet kell érteni, hogy a mérlegelési jogkörben hozott bírói döntések miatt kártérítési felelősség megállapítása már a bírói mérlegelés szabadságát kérdőjelezné meg. E körben a felelősség megállapítása a bizonyítékok kirívóan okszerűtlen mérlegelése esetén képzelhető el. (Pákozdi, 2011) Ugyanakkor szükséges arra rámutatni, és e tekintetben egyetértek Pákozdi azon álláspontjával, hogy a felróhatóság megállapításánál nem elegendő csupán a jogszabály egyértelműségét alapul venni, hanem szükséges az eset összes körülményét a vizsgálat tárgyává tenni. Különösen igaz ez az olyan esetekben, ahol a bíróságok hibája önmagában nem mondható „súlyosnak”, de az okozott kár mégis jelentősnek mondható. (BH 2013.243) Ezért aztán érdemes lenne az alapügy tárgyát, az érvényesített kárösszeget, valamint a hiba tárgyát is vizsgálni, amivel összefüggésben álláspontom szerint Pákozdi helyesen mutat rá arra a tényre, hogy az alapügy ilyen irányú vizsgálata nem sérti annak a jogerejét, és végképp nem eredményezi annak a megváltoztatását. Vogyicska is rávilágít arra az ellentmondásra, hogy úgy kell az alapügyben eljárt bíróság eljárására vonatkozó aktákat a kártéritési per bíróságának áttekintenie, és az alapján a kártérítési kereset tárgyában döntést hoznia, hogy a jogerős ítélet tartalmának az értékelését kerülnie kell. (Vogyicska, 2015) Ez a feladat véleményem szerint nem kényelmes, de a jogkeresők igényérvényesítéshez, valamint tisztességes eljáráshoz való jogának biztosítása érdekében mégis szükséges.

A bíróságok és az ügyvédek által végzett tevékenység közötti különbség ellenére a bírósági kárfelelősségnél alkalmazott felróhatósági mérce túl szigorúnak tûnik, ez pedig az ügyvédi kárfelelősséggel összehasonlítva még inkább igaz. Az ügyvédi kárfelelősség tekintetében úgy tűnik, hogy a bíróságok különösen értékelik azt a körülményt, hogy az ügyvédi tevékenység milyen felelősséggel jár együtt. A jogban járatlan ügyfelek abból a célból bízzák meg az ügyvédet, hogy az általuk elérni kívánt joghatás következzen be, legyen az egy dolgon fennálló tulajdonjog vagy egy gazdasági társaság bejegyzése, egy okirat minden releváns körülményre tekintettel lévó megszerkesztése, vagy a peres eljárásban a lehető legjobb tudása szerinti képviselet ellátása, amely kiterjed arra a gondosságra is, hogy az elóterjesztendő iratok határidőben kerüljenek benyújtásra. Ezért indokolt is, hogy a bíróságok szúk mentesülési lehetőséget engednek az ügyvédi felelôsség alól, ha bizonyítható és megállapítható, hogy az ügyfél az ügyvéd felróható magatartásának eredményeként szenvedett kárt, mivel a kérdéses jogviszonyokban a felek között lényeges információs aszimmetria áll fent, amelyet a bíróságoknak az elvárhatósági mérce megállapításánál figyelembe kell vennie. Az információs aszimmetriából és a kontraktuális felelósség alapjából, azaz abból indulva, hogy a szerződó felek a szerződés megkötése előtt mérlegelhetik saját körülményeiket, teljesítési kapacitásukat, az ügyvédi megbízás tekintetében megállapítható, hogy az ügyvédek úgy vállalják az ügyfél megbízását, 
Debreceni Jogi Múhely 2020. (XVII.) 3-4.

Debreceni Egyetem, Állam- és Jogtudományi Kar, Debrecen

(University of Debrecen, Faculty of Law, Debrecen)

DOI 10.24169/DJM/2020/3-4/11

hogy tudatában vannak saját munkaterhüknek, kapacitásuknak, ezért a kellő körültekintés elmulasztása a legtöbb esetben a felelősségük megállapítását eredményezi. Ellenben tény, hogy a bíróságok az ügyterhüket nem maguk szabályozzák, bár ez álláspontom szerint nem vezethet arra a következtetésre, hogy a bíróságok kárfelelőssége a leterheltség miatt kell, hogy enyhébb legyen, hiszen a bíróságok megfelelő jogalkalmazói tevékenységéhez füződő felelőssége talán még az ügyvédek tevékenységükért fennálló felelősségénél is nagyobb.

Ugyanakkor nem lehet azt sem kijelenteni, hogy az ügyvédek anyagi felelőssége korlátlan lenne. Mint korábban kifejtésre került, a bíróságok túlnyomórészt következetesen érvényesítik azt az álláspontot, hogy az árnyékperek lefolytatását nem tartják elfogadható megoldásnak a pernyertesség esélyének elvesztésére alapított kártéritési igényekkel összefüggésben az okozati összefüggés megállapítására, hanem az okozati összefüggés hiányában az ilyen kereseteket elutasítják. Ebben a tekintetben az ügyvédi felelősség igencsak korlátozott a bírósági gyakorlat által, hiszen ilyen módon a felek csak személyiségi jogsértés jogcímén igényelhetik a mulasztó ügyvéd sérelemdíj megfizetésére kötelezését a bíróságtól, amely viszont adott esetben elenyésző kompenzációt jelenthet csupán a fél számára ahhoz az összeghez képest, amelyhez a sikeres igényérvényesítés esetén hozzájuthatott volna. Éppen ezért egyet lehet érteni Molnárral abban a tekintetben, hogy az lenne ennek az anomáliának megoldása, ha a pernyertesség/perorvoslat lehetőségének elvesztése önálló kárfajtának minősülne. (Molnár, 2013)

Az utóbbi ügyvédi felelősséget korlátozó rendelkezés ellenére álláspontom szerint látható, hogy az ügyvédi kárfelelősséghez képest a bíróságok a kárfelelősség szempontjából milyen, akár kivételezettnek is nevezhetó pozícióban vannak. (Kovács L., 2007) Ez a jelenség pedig véleményem szerint nem elsősorban abból fakad, hogy az ügyvédi anyagi felelősség megállapítása túl enyhe feltételekhez lenne kötve, hanem abból, hogy a bírósági jogkörben okozott károkért való felelősség megállapítása feltételeinek teljesítése aránytalanul nehéz. A korábban leírt hármas védelmi gyúrű, amely a bíróságok kárfelelősségének megállapítását akadályozza, vagy legalábbis korlátozza, leginkább azzal indokolható, hogy a bíróságok, mint az állami szervezetrendszer részei, valamilyen fokú extra védelmet kell, hogy élvezzenek a tevékenységükért viselt polgári jogi felelősség alól. Azonban, azt gondolom, hogy erôsen kérdéses, hogy valóban indokolt-e egy ilyen szigorú feltételrendszert állítani a bíróságokkal szembeni igényérvényesítés elé.

Fuglinszky hivatkozik az Európa Tanács Miniszteri Bizottságának egy 2010-es ajánlására, amelyben kimondásra került, hogy a bírói mérlegelés, jogértelmezés eredményeként hozott bírói döntésekért való polgári (és fegyelmi) felelősséget csak szándékos és súlyos gondatlansággal realizált jogsértések alapozhatják meg. Maga Fuglinszky is megjegyzi azonban, és a szöveg angol megfogalmazása valóban inkább arra enged következtetni, hogy ez a tétel a bíró bírói jogkörében végzett tevékenységéért való személyes felelősségére utal, azaz a bíróságokkal szembeni kártérítési igényekre még ez a dokumentum sem tartalmaz korlátozó rendelkezésekre vonatkozó ajánlásokat. (az Európa Tanács Miniszteri Bizottságának ajánlását Fuglinszky ismerteti; Fuglinszky, 2015) Az Európa Tanács a bírói függetlenség intézményének erősitésére 2016-ban egy további akciótervet fogadott el, amely lényegében ugyanezt a tételt fogalmazta meg, de a bírósági jogkörben okozott károkért fennálló állami kárfelelősség korlátozására itt sem tettek javaslatot. (Council of Europe CM (2016) Plan of Action on Strenthening Judicial Independence and Impartiality) A helyzet tehát az, hogy a magyar bíróságok annak ellenére támasztanak kifejezetten magas elvárásokat a bíróságokkal szemben érvényesített kártérítési igényekkel szemben, hogy arra nemzetközi szinten kifejezett előírásokat találnánk. Itt érdemes megemlíteni, hogy külföldi példákat elemezve Varga Zsófia arra az eredményre jutott, hogy az Európai Unióban Horvátország, Franciaország, Olaszország és Luxemburg is hasonló modellt követ a bírósági kárfelelősség tekintetében, mint Magyarország, mivel ezekben az államokban is biztosított ugyan a bírósági jogkörben okozott károk állam általi megtérítésének lehetôsége, de a jogerôs ítéletek jogerejének védelme ezen államokban is lényeges akadályát képezi az igényérvényesítésnek. (Varga, 2016) Ez nem is túnik olyan jelentősnek, figyelembe véve, hogy kb. ugyanennyi olyan államot azonosított az EU-n belül, amelyekben a bírósági jogkörben okozott károkért való felelősség önálló felelősségi alakzatként gyakorlatilag nem létezik, más államokban pedig a kárigények érvényesítésének előfeltétele, hogy a sérelmezett bírósági döntést jogellenesnek mondják ki. Azaz, ezen államokban a kártérítési per előtt még a döntés jogellenességének megállapítása iránti pert is meg kell nyerni ahhoz, 
Debreceni Jogi Múhely 2020. (XVII.) 3-4.

Debreceni Egyetem, Állam- és Jogtudományi Kar, Debrecen

(University of Debrecen, Faculty of Law, Debrecen)

DOI 10.24169/DJM/2020/3-4/11

hogy a félnek a jogsértő bírósági döntéssel okozott kára megtérüljön. (Varga, 2016)

A bíróságokkal szembeni igényérvényesítés megnehezítését tehát elsősorban a bíróságok múködésével összefüggő jogbiztonsági követelményekkel indokolják. Kérdés azonban, hogy nem a jogbiztonság keretein belül kell-e azt is biztosítani, hogy amennyiben a bíróságok jogellenes magatartása következtében a jogalanyok kárt szenvednek, akkor hatékony eszköz álljon rendelkezésre ezen károk megtérítésére. A hatályos magyar szabályozás szerint elvárt, hogy a bírósági jogkörben okozott károk megtérítésének követelése előtt a rendes jogorvoslati lehetőségeket ki kell meríteni. Ez azonban álláspontom szerint nem lenne szabad, hogy azt jelentse, hogy amennyiben a rendes jogorvoslati lehetőségek a károsult által már kimerítésre kerültek (vagy jogorvoslati lehetőség nem is biztosított), kárának megtérítését a fél már csak egy - a bemutatottaknak megfelelően - aránytalanul kis esélyú perben követelhesse. Elvégre a rendes jogorvoslati bíróságok múködésében is szükségképpen benne van a jogértelmezési vagy jogalkalmazási hiba lehetősége, sőt, még a Kúria általi felülvizsgálat során is keletkezhetnek a félnek olyan kárai, amelyek megtérítését a Ptk. 6:549. \alapján kérheti.

\section{Konklúzió, javaslatok}

A tanulmány igyekezett a bírósági jogkörben okozott károk megtérítéséért való felelősség sajátosságait bemutatni, kontrasztba állítva az ügyvédi anyagi felelősségre irányadó jogszabályi háttérrel és joggyakorlattal. Ez alapján a bevezetésben felvetett kérdésekre a következőket lehet válaszolni.

Mint kifejtésre került, mind a bíróságok, mind az ügyvédek tevékenysége a jogszabályok és a joggyakorlat ismeretéhez, alkalmazásához kötődik. Mindkettő hivatásrendnek különös társadalmi felelőssége van, hiszen a különböző jogterületeken a jogkeresők az ő közremúködésükkel juthatnak hozzá az őket megillető igényükhöz vagy próbálhatják jogosnak vélt igényüket érvényesíteni. A vizsgálat alapján viszont úgy tủnik, hogy míg az ügyvédek anyagi felelősségének körét a joggyakorlat ezen kiemelt társadalmi felelősséggel arányosan állapítja meg, a bíróságok polgári jogi felelőssége kapcsán ez az arányosság nem figyelhető meg. Ez részben talán visszavezethetô a két felelősségi alakzat jogtörténeti kialakulására is, hiszen az állami kárfelelősség elvi gondolata nemzetközi kitekintés alapján is csupán a 18. és a 19. század fordulóján jelent meg, míg az ügyvédi kárfelelősség alapgondolata már az abszolút monarchia korában is érvényesült. (Lásd az I. Lipót által 1696-ban kiadott első ügyvédi rendtartást)

Szintén kifejtésre került az, hogy a bírósági jogkörben okozott károk megtéritéséért való felelősség deliktuális, azaz szükségképpen felróhatósági alapú felelősségi alakzat, míg az ügyvédi tevékenység során okozott károk megtérítéséért való felelősség tipikusan megbízási szerződés megszegéséből eredő károkhoz kötődik. Ettôl függetlenül tisztán a deliktuális-kontraktuális felelősség elhatárolása alapján nem indokolható az elvárhatósági mércében tapasztalható különbség, hiszen a megbízási szerződés gondossági kötelmet keletkeztet, így az ügyvédi tevékenység során történő károkozás felróhatóságát is vizsgálnia kell az adott perben eljáró bíróságnak.

Összességében az mondható el, hogy a bírósági jogkörben okozott károk megtérítéséért való felelősség elé emelt, korábban említett „hármas védelmi vonal” eredményeként a bíróságokkal szembeni igényérvényesítés azon esetekben is rendkívül nehéz, amikor egyébként a felelősség általános és speciális feltételei fennállnak, mert a kirívóan súlyos jogsértés doktrínáját a bíróságok a felelősség negatív megállapítása indokaként gyakorlatilag minden olyan esetben felhívhatják, amikor a bíróság felelőssége nem olyan jogszabály megsértésén alapul, amely gyakorlatilag semmilyen mérlegelést nem tesz lehetôvé a bíróságok számára. Ez pedig végső soron ahhoz vezet, hogy a bíróságokkal szemben indított kártérítési perekben a statisztikák alapján 1-5 \% esélye van a feleknek a pernyertességre, ami sokatmondónak látszik, és már-már felveti a tisztességes eljáráshoz való jog tényleges érvényesülésének kérdését. Ezért álláspontom az, hogy a kirívóan súlyos jogsértés doktrínáját a bírósági joggyakorlatnak sokkal szűkebb körben kellene alkalmaznia. A doktrína teljes elvetését ugyanakkor nem tartom indokoltnak, mivel az a pervesztességükbe belenyugodni képtelen jogalanyok számára további ösztönzést jelentene a bíróságokkal szembeni kártérítési perek megindítására. Ebből kifolyólag azt sem tartom indokoltnak, hogy jogalkotói szinten kerüljön korlátozásra vagy kizárásra a kirívóan súlyos 
Debreceni Jogi Műhely 2020. (XVII.) 3-4.

Debreceni Egyetem, Állam- és Jogtudományi Kar, Debrecen

(University of Debrecen, Faculty of Law, Debrecen)

DOI 10.24169/DJM/2020/3-4/11

jogsértés doktrínája, hiszen annak jellegéből adódóan a jogalkalmazási gyakorlat feladata a doktrína tartalmának alakítása. Ezzel összefüggésben, Vogyicska Petra nyomán nem tartom elvetendőnek annak törvényi szintủ kimondását, hogy a bírósággal szembeni kártérítési perben eljáró bírósággal szemben ne lehessen újabb kártérítési pert indítani, mivel ez egy ördögi kört tenne lehetôvé, amely mindenképpen elkerülendő, hiszen ilyen esetben az újabb kártérítési perben eljáró bíróság már két alapügyet kellene, hogy vizsgáljon, amely rendkívül bonyolult és átláthatatlan bizonyítást tenne indokolttá. (Vogyicska, 2015) Pákozdi korábbi javaslatát, mi szerint akár egy, a rendes bíróságoktól elkülönült bírósági szervezetrendszer hatáskörébe is érdemes lenne utalni a bírósági jogkörben okozott károk megtérítése iránti pereket, nem tartom indokoltnak, ezt az ügyek mennyisége nem indokolja, valamint a Pp. kizárási szabályai és az eljáró bíróság kijelölésének lehetősége a független ítélkezésre véleményem szerint elégséges biztosíték. (Pákozdi, 2011)

Fontosnak tartom ugyanakkor, hogy a bírósági gyakorlatnak el kellene mozdulnia arról az évtizedes nyugvópontról, hogy a bírósági jogkörben okozott károk megtérítését a jogerős döntések tartalmi immunitása alapján zárják ki. A korábban kifejtetteknek megfelelóen a Bszi. és a Pp. vonatkozó rendelkezései az Európai Unió Bírósága és az Alkotmánybíróság korábbi döntései alapján sem zárják ki az ilyen igények érvényesíthetőségét. Ezzel összefüggésben szükséges megemlíteni, hogy az újabb bírósági gyakorlatban már találhatóak olyan döntések, amelyek elszakadni látszanak a jogerôs döntés tartalmi immunitása elvének előbbiekben leírt alkalmazásától. (BDT 2017.3612, PJD 2017.6)

Összességében tehát az állapítható meg, hogy a bírósági jogkörben okozott károk megtéritése iránti igények érvényesítése a hatályos jogszabályi keretek között, az irányadó joggyakorlat alapján jelentős akadályokba ütközik. Különösen igaz ez, ha a bíróságokkal szemben támasztott elvárhatósági mércét az ügyvédi anyagi felelósségnél alkalmazott elvárhatósági mércével hasonlítjuk össze. Azt gondolom azonban, hogy elsősorban nem az ügyvédi felelősség enyhítése, hanem a bíróságok felelősségének szigorítása hatna abba az irányba, hogy a joghoz jutás két kulcsszereplőjének polgári jogi felelőssége megfelelő összhangba kerüljön azok társadalmi felelősségével.

Bibliográfia

Felhasznált irodalom

VÉKÁS Lajos - GÁRDOS Péter (szerk) (2018): Kommentár a Polgári Törvénykönyvről szóló 2013. évi V. törvényhez

VOGYICSKA Petra (2015) A bírósági jogkörben okozott kár gyakorlata a polgári eljárásban, In: Magyar Jog 2015/3. szám, 163 p.

Borbás Beatrix (2014): A bírói hatalom kárfelelőssége, Budapest, HVG-ORAC Lap és Könyvkiadó Kft, 117, 119-120, 140, 167 pp.

FUGLINSZKY Ádám (2015) Kártéritési jog, Budapest, HVG-ORAC Lap és Könyvkiadó Kft., 2015, 65, 107. 283. 287, 537, 538, 539, 547 pp.

PRIBULA László (2014) Kivételes-e a jogalkalmazó felelőssége?, In: Jogtudományi Közlöny, 2014/11. szám, 517, 518 pp.

TŐKEY Balázs (2017) A jogalkotással okozott kárért való felelősség, In: Polgári Jog 2017/4 [28] bekezdés

LÁBADY Tamás (2016) Sérelemdíj versus nem vagyoni kártérítés, In: Állam- és Jogtudomány LVII. évfolyam, 2016/1. szám, 40 p.

Sopovné dr. Bachmann Katalin (2009) Bírósági jogkörben okozott kártérítési felelősség, In: Magyar Jog 2009/1. szám, 25 p.

Kemenes István (2017) A kontraktuális kártérítés egyes kérdései, In: Magyar Jog, 2017/1. szám, 1. p., 8. p.

SÁNDOR István - SZÜCS Brigitta (2014) Az ügyvédi felelősség és biztosítása, Budapest, HVG- 
Debreceni Jogi Műhely 2020. (XVII.) 3-4.

Debreceni Egyetem, Állam- és Jogtudományi Kar, Debrecen

(University of Debrecen, Faculty of Law, Debrecen)

DOI 10.24169/DJM/2020/3-4/11

ORAC Lap és Könyvkiadó Kft, 105 p.

FUGLINSZKY Ádám - TŐKEY Balázs (2018) Szerződési jog - Különös rész, Budapest, ELTE Eötvös Kiadó Kft., 310 p.

MOLNÁR Levente (2013) A Kúria ítélete az ügyvédi felelősségről és az árnyékperek lefolytatásának tilalmáról, In: Jogesetek Magyarázata, 2013/3., 21-22. pp.

CSÖNDES Mónika (2017) Az anyagi jogi norma jelentősége és a bizonyítási teher összefüggései a kártérítési felelősség tényállási elemei szempontjából, valamint ezek hatása az itéleti tényállás megállapítására; In: Kúria Joggyakorlat-elemző Csoportjának Összefoglaló Véleménye: Az ítéleti bizonyosság elméleti és gyakorlati kérdései, 2017, Mellékletek 41. o., elérhető itt: https://kuriabirosag.hu/sites/default/files/joggyak/melleklet_iteleti_bizonyossag.pdf, utolsó letöltés dátuma: 2020. 11. 30 .

PÁKOZDI Zita (2015) A Fơvárosi Ítélótábla ítélete a bírósági jogkörben okozott károkért való felelősségről, In: Jogesetek Magyarázata 2015/3, 47 p.

PÁKOZDI Zita (2011) A bírói jogkörben okozott károk megtérítése és a tisztességes eljárás, In: Miskolci Jogi Szemle 2011/2., 93, 97 pp.

KOVÁCS L. László (2007) A bírói felelősség a polgári eljárásjogban és azon kívül, In: Magyar Jog 2007/11., 666 p.

VARGA Zsófia (2016) The Application of the Köbler Doctrine by Member State Courts, In: ELTE Law Journal 2016/2., 75, 76 pp.

CSÉCSY Andrea - KISS Tibor - VARGA Nelli (2019) Kártérítési jog. A kontraktuális és deliktuális kárfelelősségi rendszer a 2013. évi V. törvény alapján, Debrecen, Debreceni Egyetem, Állam- és Jogtudományi Kar, 37 p.

Hivatkozott bírósági döntések

53/1992. (X. 29.) AB határozat

Fővárosi Ítélőtábla Pf. 20.149/2019/4.

Debreceni Ítélőtábla Pf. 20.289/2011

Kúria Pfv. 20.185/2016/7, [18] bekezdés

BH 2008.120

LB Pf. 25.292/2000

BH 2003.154

BDT 2017.3720

LB Pf. 25.079/2001/4.

BH 1993.32

BH 2000.55

BH 2003.65

BH 2009.9

BDT 2006.1496

Győri ítélőtábla Pf. 20.070/2015

Fôvárosi Törvényszék P.22.586/2015

778/D/2000. AB határozat

339/B/2003. AB határozat 
Debreceni Jogi Múhely 2020. (XVII.) 3-4.

Debreceni Egyetem, Állam- és Jogtudományi Kar, Debrecen

(University of Debrecen, Faculty of Law, Debrecen)

DOI 10.24169/DJM/2020/3-4/11

Fôvárosi Ítélőtábla Pf. 21.115/2014/6

BH 2018.141

BH 2015.158

Pécsi Ítélőtábla Pf. 20.555/2013/5

BH 2009.325

BDT 2008.1817

BH 2013. 243

LB Pf. V. 20.622/1997

Kúria Pfv. III. 20.871/2014

BDT 2016.3511

BDT 2017.3650

BH 2009.15. III. pont

EBH 2002.751

BH 2013.243

LB Pfv. 21.287/1996/4

EBH 2006.1410

BDT 2009.1984

BDT 2007.1689

Kúria Pfv. 21.816/2013

Kúria Pfv. 20.747/2016

Kúria Pfv. 21.456/2016

Kúria Pfv. 20.158/2017

BDT 2009.1948

Kúria Pfv. 20.065/2012

BH 2016.244

BDT 2007.1564

Kúria Pfv. 20.956/2017

BDT 2002.580

LB Pfv. 21.129/2009

LB Pfv. 20.928/2010 (BH 2012.90 szám alatt közzétéve)

BH 2013.89

BDT 2017.3612

PJD 2017.6

Egyéb források

Az új Polgári Törvénykönyv koncepciója, In: Magyar Közlöny 2002/15/II. szám, 174. o.

T/15371. számú javaslat az Üttv.-ről, $120 . \quad$ o, elérhető itt: https://www.parlament.hu/irom40/15371/15371.pdf, utolsó letöltés dátuma: 2020. 11. 30. 
Debreceni Jogi Mühely 2020. (XVII.) 3-4.

Debreceni Egyetem, Állam- és Jogtudományi Kar, Debrecen

(University of Debrecen, Faculty of Law, Debrecen)

DOI 10.24169/DJM/2020/3-4/11

11/2017. (XI. 20.) MÜK szabályzatot az okiratszerkesztésről és az elektronikus ügyintézésről

A Magyar Ügyvédi Kamara, az ügyvédi ellenjegyzés jó gyakorlatairól című tájékoztatója (2019. május 1.), elérhető itt: https://magyarugyvedikamara.hu/common/fileservlet/document/1407/default/doc_url/Ugyvedi_ellenjegyzes_tajekoztato_MUK.pdf, utolsó letöltés dátuma: 2020. 11. 30.

OBH elnöki beszámolók, 2014-2018:

Az Országos Bírósági Hivatal Elnökének 2018. évi beszámolója, 125. o., elérhető itt: https://birosag.hu/sites/default/files/2019-10/eves_beszamolo_2018_0.pdf, utolsó letöltés dátuma: 2020. 11. 30 .

Az Országos Bírósági Hivatal Elnökének 2017. évi beszámolója, 117. o., elérhető itt: https://birosag.hu/sites/default/files/2018-10/beszamolo2017.pdf, utolsó letöltés dátuma: 2020. 11. 30.

Az Országos Bírósági Hivatal Elnökének 2016. évi beszámolója, 165. o., elérhető itt: https://birosag.hu/sites/default/files/2018-09/2016_eves_beszamolo.pdf, utolsó letöltés dátuma: 2020. 11. 30.

Az Országos Bírósági Hivatal Elnökének 2015. évi beszámolója, 152. o., elérhető itt: https://birosag.hu/sites/default/files/2018-09/2015_eves_beszamolo_0.pdf, utolsó letöltés dátuma: 2020. 11. 30 .

Az Országos Bírósági Hivatal Elnökének 2014. évi beszámolója, 146. o., elérhető itt: https://birosag.hu/sites/default/files/2018-09/2014_eves_beszamolo.pdf, utolsó letöltés dátuma: 2020. 11. 30.

Az Európa Tanács Miniszteri Bizottságának ajánlásának a bírói függetlenség, hatékonyság és felelősség tárgyában (Recommendation CM/Rec(2010)12 of the Committee of Ministers to member states on judges: independence, efficiency and responsibilities) a vonatkozó részét Fuglinszky ismerteti, i.m. 547. O.

Council of Europe CM (2016) Plan of Action on Strenthening Judicial Independence and Impartiality, elérhető itt: https://rm.coe.int/1680700125, utolsó letöltés dátuma: 2020. 11. 30. 